\title{
Az intézményi hatás és modelljeinek vizsgálata közép-kelet-európai felsőoktatási intézmények sportjában
}

\begin{abstract}
Absztrakt
Tanulmányunk célja, hogy feltárja, milyen intézményi környezeti tényezők jellemzik néhány kárpát-medencei felsőoktatási intézmény sportéletét. Fő kérdésünk, hogy az intézményi hatás modelljei hogyan jelennek meg a sport területén a vizsgált felsőoktatási intézményekben, milyen tényezők miként befolyásolhatják a hallgatók sportolási szokásait. Az intézményi hatás tényezőinek megragadásához nemzetközi modelleket vettünk alapul. Feltáró kutatásunk célja, hogy megnézzük, ezek a modellek milyen módon és formában jennek meg a vizsgált felsőoktatási intézmények sportjában. Tanulmányunkban bemutatjuk az intézmények sport, illetve konstruált környezetét, szervezeti és infrastrukturális hátterét, valamint az oktatók szerepét.
\end{abstract}

Kulcsszavak: sportolási szokások, felsőoktatás, intézményi háttér

\section{Bevezetés $^{1}$}

Az egyetemek és főiskolák nagyon komplex szervezetet alkotnak számtalan szereppel és funkcióval. A hagyományos oktatási funkción kívül kétségtelenül megjelenik a civil társadalmi küldetés, ami fontos szerepet játszik a helyi közösség, gazdaság, társadalom fejlődésében (Casper, Pfahl \& McCullough, 2014). Ugyanakkor az egészségfejlesztés kevésbé jelenik meg a felsőoktatási intézmények stratégiai céljaiban, küldetésében, képzési, kutatási és harmadik missziós feladatrendszerében, miközben például az UNESCO (2015) a Fenntartható Fejlődési Célok között is megfogalmazza, hogy biztosítani kell az egészséget és elő kell mozdítani a jóllétet minden korosztály számára. Pedig az egészségtudatos egyetemek növelhetik a versenyképességet, minőséget, szakmai presztízst, javíthatják az intézmény társadalmi megítélését, a tanulási-munkahelyi környezetet és a hallgatók teljesítményét, csökkentve a

\footnotetext{
${ }^{1}$ A tanulmány a 123847 számú projekt a Nemzeti Kutatási Fejlesztési és Innovációs Alapból biztosított támogatással, a K17 pályázati program finanszírozásában valósult meg. A tanulmány megírását a Magyar Tudományos Akadémia Bolyai János Kutatási Ösztöndíja támogatta.
} 
lemorzsolódást (Kraiciné, 2016; Bárdos \& Kraiciné, 2018). A hallgatók sportolási szokásainak mint az egészségmagatartás fontos területének és az ezeket meghatározó tényezők vizsgálatának relevanciáját támasztja alá az a tény, hogy e korosztályt tekintve a hallgatókat tudjuk a legkönnyebben elérni a rendszeres sportolás számára, hiszen a felsőoktatás a számukra még egy utolsó lehetőséget ad a szervezett keretek között zajló sportolásra (Pfau, 2014). Ezen a területen sok pozitív folyamat indult el, de még mindig azt láthatjuk, hogy ezek a szabadidős programok, kezdeményezések sok hallgatóhoz nem jutnak el, vagy nem foglalkoznak vele, így jelentős hányaduk életmódjára inaktivitás jellemző (Gősi, 2018). A felsőoktatási intézmények egyik legfontosabb feladata ezen a területen, hogy a szabadidősport-programok és események tervezésénél figyelembe vegyék a hallgatói igényeket (Pfau \& Domonkos, 2016; Galan, Zoriy, Briskin \& Pityn, 2017). Ezek közül is kiemelkedik a közelség és az olcsóság (Kozma, Szabó \& Huncsik, 2016; Pfau, 2014), amely két kritériumnak a felsőoktatási intézmények bizonyos feltételek mellett könnyebben meg tudnak felelni. A felsőoktatási intézmények szerepe és jelentősége kiemelkedő a hallgatók sport iránti pozitív attitűdjeinek kialakításában és fenntartásában.

Az (épített) környezet jellemzőinek hatása a fizikai aktivitásra kevésbé kutatott terület (Sallis, Bowles, Bauman, Ainsworth, Bull, Craig \& Matsudo, 2009; Prins, van Empelen, te Velde, Timperio, van Lenthe, Tak \& Oenema, 2010), illetve általánosságban a fiatalok sporttapasztalatainak társadalmi és kulturális aspektusai egy ritkábban alkalmazott megközelítés szemben pl. a pszichológiai tényezőkkel (Macphail, Gorely \& Kirk, 2003), miközben az egészségtudományi szakirodalom már régóta felismerte a fizikai aktivitás szocioökológiai megközelítésének (pl. az ökológiai modell) fontosságát. Ez egyaránt tartalmazza a társadalmi és fizikai környezet, társas támogatás (család, barátok, munkahely vagy iskola), kulturális normák és gyakorlatok, valamint a policy szerepét az egészség, egészségmagatartás, s ezekegyes dimenzióinak, úgy mint a fizikai aktivitás, egyenlőtlenségeiben (Soos, Dizmatsek, Ling, Ojelabi, Simonek, Boros-Balint, Szabo, Szabo \& Hamar, 2019; Wiltshire, Lee \& Williams, 2019).

Tanulmányunk célja, hogy feltárja, milyen intézményi környezeti tényezők jellemzik néhány kárpát-medencei felsőoktatási intézmény sportéletét. Fő kérdésünk, hogy az intézményi hatás modelljei hogyan jelenek meg a sport területén a vizsgált felsőoktatási intézményekben, milyen tényezők miként befolyásolhatják a hallgatók sportolási szokásait. $A z$ intézményi hatás tényezőinek megragadásához nemzetközi modelleket vettünk alapul, 
melyeket hazánkban észak-alföldi, illetve felvidéki, kárpátaljai, vajdasági, erdélyi és partiumi, elsősorban kisebbségi magyar felsőoktatási intézményekben teszteltünk. Feltáró kutatásunk célja, hogy megnézzük, ezek a modellek milyen módon és formában jennek meg a vizsgált felsőoktatási intézmények sportjában. Az empirikus vizsgálathoz interjúkat készítettünk ezeken az egyetemeken/főiskolákon vezetőkkel és testnevelőkkel.

\section{Az intézményi hatás és környezet}

A felsőoktatás-kutatások többsége alapul vesz szervezetelméleti megközelítéseket (Szolár, 2009). Különböző vizsgálatok az 1970-es évektől foglalkoznak a felsőoktatási intézményekkel szervezetként, melyek értelmezéséhez elsősorban el kell különíteni az intézmény (institution) és a szervezet (organisation) definícióját. Amíg a szervezeteket olyan szerveződéseknek értelmezzük, amelyeken keresztül emberek cselekednek, addig az intézmények olyan egységes normák és érdekek, amelyek meghatározzák ezeket a cselekvéseket (Berg, 2007). Több diszciplína (szociológia, pszichológia, gazdaságtudomány) is foglalkozott a szervezeti témák kutatásával. A neveléstudomány a szervezetpedagógiát saját aldiszciplínájaként határozta meg. A témában folytatott vizsgálatok középpontjába a szervezeti tanulás fogalmáhelyezik (a szervezetek tanulását, szervezetekben zajló tanulást és a szervezetek közötti tanulást) (Göhlich, Weber \& Schröer, 2016).A szervezetpedagógiai megközelítés jól alkalmazható a felsőoktatási intézmények elemzésére (Euler, 2018). Göhlich et al. (2016) szerint a szervezeti tanulás (mezo-szintként meghatározva) jelenségei nem magyarázhatók annak társadalmi és intézményi környezete (makro szint), valamint az egyéni tanulási folyamatok (mikro szint) megfigyelése nélkül.

A felsőoktatási intézmények szervezeti kultúráját több kutatás is vizsgálta (Smart \& John, 1996; Sporn, 1996; Silver, 2003; Schein, 2010; Chatman \& O’Reilly, 2016). Az említett szerzők mindannyian rámutatnak a felsőoktatási intézmények egészként való meghatározásának nehézségére és az eltérő szubkultúrák (pl. különböző diszciplínák; adminisztratív - akadémiai stb.) hatására. Smerek (2010) is figyelembe veszi ezeket a szempontokat, a felsőoktatási intézmények egy adott felsőoktatási rendszerbe, valamint a nemzeti kultúrába való beépülését, továbbá utal az esetleges nemi és etnikai különbségekből eredő meghatározottságokra is. Vizsgálatunkban a felsőoktatási szervezetek komplex 
rendszerének egy szeletét, a makro szint (az intézményi környezet) átvilágítását helyezzük a középpontba.

Kutatásunk másik elméleti hátterét az intézményi hatás koncepciójára és az erre vonatkozó elméletekre, modellekre alapozzuk (Pascarella \& Terenzini, 2005). Az intézményi hatás azokat a tényezőket vizsgálja, melyek befolyásolják a hallgatók változását a felsőoktatási évek alatt, legyenek ezek, értékek, magatartás, viselkedés vagy éppen az eredményesség. A hallgatói fejlődést és változást vizsgáló elméleti modelleket alapvetően két csoportba sorolhatjuk: a fejlődési elméletek vagy modellek az individuális fejlődés természetét, struktúráját és folyamatát vizsgálják, tehát alapvetően az egyénben történő változásokra fókuszálnak, s leginkább pszichológiai kategóriákkal, elméleti kerettel dolgoznak (pl. Erikson, Piaget elméleteire alapozva). Tanulmányunkban a hallgatói változásra vonatkozó másik nagy elméleti családra építünk, az intézményi hatásra, amely az egyének közötti és környezeti tényezőkből eredezteti a változást, s ez nem feltétlenül jár együtt pozitív fejlődéssel, progresszióval, egyéni növekedéssel. Az intézményi hatás számos tényezőből tevődik össze: ezek egy része a hallgatókra vonatkozik (nemi, etnikai, szocio-kulturális, tanulmányi eredményességre vonatkozó különbségek), de lehetnek strukturális vagy szervezeti jellemzők (az intézmény mérete, szelekciós mechanizmusok, kurrikulumok), továbbá vannak környezeti feltételek (a karok vagy a hallgatók által létrehozott kulturális, társadalmi, politikai klíma). A két elméleti család között a legfontosabb különbség, hogy az előbbi a mire, míg az utóbbi a hogyanra keresi a választ. Az intézményi hatást vizsgáló modellek a változás forrásaira fókuszálnak (pl. intézményi jellemzők, programok, szolgáltatások, hallgatói tapasztalatok, a hallgatók és oktatók közötti interakciók) (Pascarella \& Terenzini, 2005). Kutatásunkban is azokat az intézményi erőforrásokat vizsgáljuk, melyek hatással lehetnek a hallgatók sportolási szokásaira: sportszervezeti jellemzők, célok, értékek, misszió mint kampuszkörnyezeti faktorok, versenysport szerepe és felépítése, sportszolgáltatások (programok, események), személyi tényezők a sportra vonatkozóan, infrastrukturális feltételek.

Az intézményi hatást vizsgáló modellek közül azokat a kampusz-környezeti tényezőkre fókuszáló elméleteket és modelleket alkalmazzuk kutatásunk során, melyek befolyásolják az egyén sporthoz kapcsolódó magatartását. Ezeket a modelleket Strange (2003) négy kategóriába sorolta, melyek teljes mértékben megfelelnek a kampusz-környezet vizsgálatához szükséges kritikus elemeknek (Museus, 2017): 
1. Fizikai modellek: ezek az elméletek és modellek a külső fizikai környezet hatásaira fókuszálnak, melyek meghatározhatnak bizonyos viselkedési formákat, illetve lehetőségeket biztosítanak bizonyos tevékenységekhez (pl. konditermek, parkok, eszközök, pályák, csarnokok a sportoláshoz). Ide tartoznak a témánk szempontjából fontos sportinfrastruktúrák. Az egészségmagatartás vizsgálatát célzó szocio-ökológiai modellek azokat a személyes, társadalmi és intézményi, valamint fizikai környezeti tényezőket vizsgálják, mint pl. a sportlétesítmények elérhetősége, amik befolyásolhatják az egyén viselkedését, s hangsúlyozzák, hogy e tényezők többdimenziós elemzésére van szükség ahhoz, hogy megértsük és megváltoztathassuk az egyéni viselkedési formákat az egészségre vonatkozóan. Az olyan környezeti tényező, mint pl. a sportlétesítményekhez való hozzáférés facilitátorként múködhet az egészségtudatos magatartással összefüggésben (Pan, Cameron, DesMeules, Morrison, Craig \& Jiang, 2009; Prins et al., 2010).

Kutatási eredmények igazolják, hogy minél támogatóbb a fizikai környezet egy helyi közösségben és hozzáférhetőbbek, megfizethetőbbek, civilizáltabbak és biztonságosabbak a sportlétesítmények (megfelelő járdák, utak, parkok sétához, kerékpározáshoz, futáshoz, sportolásra kialakított terek, létesítmények), annál valószínúbb, hogy egy ott lakó fizikailag aktív lesz (Sallis et al., 2009; Pan et al., 2009; Bácsné Bába, Fenyves, Szabados, Pető, Bács \& Dajnoki, 2018). A legnagyobb hatása a megfelelő minőségű járdáknak volt a fizikai aktivitás valószínűségére (Sallis et al., 2009). Más vizsgálatban, noha a sportlétesítményekhez való hozzáférésnek nem volt közvetlen hatása a sportolásra serdülők körében, ugyanakkor indirekt pozitív hatás mutatkozott a sportszándékon keresztül (Prins et al., 2010). Hazai felsőoktatási hallgatók sportolását vizsgálva azonban azt láthatjuk, hogy kétszer annyian mozognak a kampuszokon kívül, mint azon belül, különösen a nők körében vonzóak kevésbé az egyetemi sportolási lehetőségek. Pfau és Domonkos (2016) sportvezetők véleményét összegezve arra jutott, hogy kétharmaduk elégedetlen az egyetemük sportinfrastruktúrájával, háromnegyedük pedig a meglévő anyagi feltételekkel, s fontos feladatnak tekintik a fejlesztéseket ezen a területen.

2. Emberi erőforrásra koncentráló modellek: ezek az elméletek az emberi környezet befolyásoló szerepét vizsgálják (pl. szociokulturális sajátosságok, értékek, attitűdök). Ily módon azt vizsgálják, a különféle szocializációs közösségek (tanárok, egyetemi munkatársak, hallgatótársak) miként hatnak egymásra, s hogyan osztják meg egymással értékeiket, attitűdjeiket, érdeklődési körüket, magatartásukat. Esetünkben a vizsgálandó kérdés, hogy az 
egyetem tagjainak (főként hallgatók, vezetők és oktatók) sportolása, sporthoz kapcsolódó attitúdje, miként befolyásolja a hallgatók sportolási szokásait. Pfau és Domonkos (2016) 18 hazai felsőoktatási intézményre kiterjedő vizsgálatának eredményei rávilágítanak arra a fontos problémára, hogy egyes egyetemeken azért nehéz szabadidősport-rendezvényeket szervezni, mert az intézmény vezetői nem állnak támogatóként a háttérben. A sportért felelős egyetemi vezetők, testnevelők, edzők számára motiváló erőként hat, ha elismerik, segítik munkájukat és nem ütköznek falakba a megvalósítás során. Ugyanakkor azt is megjegyezték, hogy a hallgatók részéről a motiválatlanságot és lustaságot teszik felelőssé a szabadidősport iránti népszerűtlenségért. A hallgatók részéről azonban fontos motiváló erőként hatnak az oktatók, mivel az ingyenesség és olcsóság után az oktató személyisége a legfontosabb indok a kampuszon történő sportolásra, míg a barátok szerepe kiemelkedik az egyetemen kívül végzett sporttevékenységben (Pfau, 2016).

Korábbi kutatásunkban megvizsgáltuk a társadalmi háttérváltozók, az egészségmagatartás kontextuális hatásainak (az intézményre vagy karra, mint mezoszintű tényezőre jellemző egészségmagatartási formák), a hallgatók (inter- és intragenerációs) beágyazottságának, valamint az önkéntes civil közösségi részvétel mint társas hatások befolyásoló szerepét az egészségrizikó-magatartásformák kerülésének esélyére kárpátmedencei hallgatók körében (Pusztai, Kovács, Kovács \& Nagy, 2017). Eredményeink felhívják a figyelmet a kampuszkultúra, miliő kiemelkedő szerepére az egészségtudatos magatartás összefüggésében: a rizikókerülő kampusztársadalomban kétszer akkora esélye van a hallgatónak elkerülni az egészségkárosító szokásokat, ugyanakkor a kortársak közé való erős, multiplex beágyazódás szignifikánsan növeli a rizikómagatartás esélyét. Az önkéntes közösségi részvétel mint civil, társas tevékenység szignifikáns mértékben képes pozitív irányba mozdítani a hallgatói magatartást.

3. Szervezeti környezeti modellek: az intézményi célok, értékek és tevékenységek alkotta rendszer, melyek kialakítják az intézményi struktúrát és dizájnt. Ide tartoznak azok az intézményi szervezeti jellemzők, amik hatással vannak a működésre, arra, hogy milyen üzenetet közvetít magáról az intézmény, s ezt milyen módon érvényesíti rendszer szinten.

Jellemzői:

- a strukturális keret (hogyan épül fel a szervezet a céljainak elérése érdekében), 
- az emberi erőforrás kerete (a szervezetben dolgozó emberek motivációira, szükségleteire, elköteleződésére, képzésére, alkalmazására és szocializációjára fókuszál),

- a politikai keret (segít megérteni a vezetőknek azokat a módszereket és folyamatokat, amik segítségével egy olyan közös vízió építhető ki, ami mobilizálja az embereket, meggyőz másokat, meghatározza az erőforrásokat a sikerhez),

- és a szimbolikus keret (misszió, vízió, értékek, melyeket rituálékon és ünnepségeken keresztül közvetít az intézmény, s alátámaszt olyan tevékenységeket, gyakorlatokat, policy-t, melyek tipikusan mellőzöttek) (Kezar, 2017).

Ahhoz, hogy megértsük, egy intézmény szervezete hogyan tud alkalmazkodni a folyamatos társadalmi kihívásokhoz Kezar (2017) szerint a szervezeti kultúrát és a jelentésadást kell megvizsgálni. Témánk szempontjából a kampusz-kultúra normák, értékek, elvárások, hiedelmek tartós mintázatait jelentik, melyek alakítják az egyének és csoportok magatartását az egyetemen/főiskolán, s ami értelmezi, keretet ad a kampuszon és azon kívül történő eseményeknek, tevékenységeknek. A kampusz-kultúra három szintje ismeretes: termékek, értékek, valamint alapvető feltételezések és hiedelmek. A termékek a kampusz-kultúra szimbolikus aspektusait jelölik, látható bizonyítékai a kultúra múködésének. Ide tartoznak pl. a beavatási szertartások az elsőévesek esetében, vagy a hagyományok, közösségi sztenderdek és elvárások. Ilyen termékek a kampuszra jellemző nyelvfordulatok/használat, emlékezetes történetek, melyek generációról generációra adódnak át. Az értékek a kampusz által elfogadott és közvetített eszméket jelentik. A diverzitás, az intellektuális szabadság vagy éppen a kritikai gondolkodás mint értékek általában explicit módon jelennek meg az intézmények küldetéstudatában. Az alapvető feltételezések és hiedelmek nem jelennek meg ennyire explicit módon egy intézmény életében, mint az értékek, de legalább olyan mértékben képesek befolyásolni a gondolkodást, eszméket, percepciókat és érzelmeket a kampuszokon (Renn \& Patton, 2017).

A felsőoktatási intézmények esetében a sportkoncepció vizsgálata jelenti azt a keretet, amiből megismerhetjük a sport tényleges és szimbolikus szerepét az intézmények életében. $A$ sportkoncepció azokat a feladatokat és megoldásokat tartalmazza, amik segítik a hallgatókat az egészségtudatos életmód elsajátításában, s ennek részeként az élethosszig tartó sportszocializációban. Ebben három terület különül el: az oktatási feladatok (testnevelés órák, kötelezettségek teljesítésének megszervezése), szabadidősport-események, -rendezvények, - 
programok és a versenysport lehetőségek biztosítása (Pfau, 2006). Pfau (2014) országos kutatásából kiderül, hogy a szabadidősport szervezési feladatait szinte miden vizsgált intézményben a testnevelők látják el, kivéve az ELTE-n, ahol egyesületük, a BEAC koordinálja. A versenysport esetében a testnevelő tanárok mellett a Hallgatói Önkormányzat is megjelenik, mint szervező. A kutatás fő következtetése, hogy a szabadidősport-rendezvények képesek megmozgatni a hallgatókat a legnagyobb arányban, így egyértelmű, hogy erre kell fektetni a legnagyobb hangsúlyt.

A sport szempontjából fontos kérdés, hogy az intézmény küldetéstudatában, életében, történetében, a kampusz-kultúrában milyen szerepet tölt be a sport valamilyen formája, hogyan, milyen értékek mentén szervezi a sportéletet, milyen rendezvényeket, programokat nyújt, s ebben milyen rendszert, hogyan múködtet.

4. Konstruált környezet: korábban Pascarella \& Terenzini (2005) ezeket a modelleket perceptuális modelleknek nevezte, utalva ezek szociálpszichológiai és kulturális antropológiai megközelítéseire, s Strange (2003) elnevezése is a résztvevők percepcióira, értékelésére, tapasztalataira utal az intézményi összetevők jellemzőire vonatkozóan. Témánk szempontjából ez a dimenzió a hallgatók véleményét és értékítéletét jelöli az intézmény által nyújtott sportolási lehetőségekre vonatkozóan. Ez azért is fontos, mert egy korábbi hazai vizsgálat szerint a sportvezetők 87\%-a elégedetlen volt azzal, ahogy a felsőoktatási intézmények motiválják a diákokat sportolásra (Pfau \& Domonkos, 2016), ugyanakkor az intézmény nyújtotta szabadidősport-lehetőségeket 89\%-uk elfogadhatónak vagy annál jobbnak minősítette (Pfau, 2016). Mivel kvalitatív vizsgálatunkban az intézmények felől közelítettük, s nem kérdeztünk meg hallgatókat, ezt a kérdéskört jelen tanulmány keretében nem, de a vizsgálat folytatásaként jelenleg zajló hallgatói kérdőíves kutatás keretében tudjuk majd megvizsgálni. A tanulmányunk alapját képező kutatásunkból ehhez a témakörhöz kapcsolódóan azt tudjuk megnézni, hogy miként szereznek információkat a hallgatóktól a sportolási szokásaikra, és sporthoz kapcsolódó intézményi elvárásaikra vonatkozóan, s mit kezdenek ezekkel az adatokkal. Továbbá azt is megtudhatjuk, hogy az interjúalanyok hogyan látják a hallgatók sporthoz kötődő attitűdjeit, tehát az ő percepcióikat ismerhetjük meg.

\section{Kutatási kérdések és módszertani háttér}


Feltáró kutatásunkban azt vizsgáljuk meg, hogy az intézményi hatás fent bemutatott elméleti modelljei hogyan jelennek meg kárpát-medencei felsőoktatási intézmények sportéletében. Hogyan manifesztálódnak ezek a dimenziók, illetve milyen hasonlóságokat és különbségeket fedezhetünk fel a vizsgált intézmények sportjában a fizikai, szervezeti, személyi és konstruált környezet vonatkozásában? Hogyan befolyásolhatják ezek a tényezők a hallgatók sportolási szokásait az intézmény és képviselőinek szemszögéből?

A kutatás keretében strukturált interjúkat készítettünk hazai és négy határon túli térség 14 felsőoktatási intézményében (15 db). Az intézmények kiválasztásában a legfontosabb elv az volt, hogy kapcsolódjon a Felsőoktatási Kutató és Fejlesztő Központ (CHERD-H) korábbi empirikus vizsgálataihoz, melyek keretében kvantitatív módon vizsgáltuk meg a hallgatók sportolási szokásait, illetve az ezeket meghatározó szociokulturális és individuális tényezőket (Kovács, 2015; 2019). Az intézményi környezet vizsgálatára azonban csak részben nyílt lehetőségünk (Kovacs, Lentene, Moravecz, Rabai \& Bacsne Baba, 2018), így az intézményi hatás mérésének megalapozásához végeztük el a jelen tanulmányban bemutatott kvalitatív kutatást. A következő intézményekben készültek az interjúk:

- Debreceni Egyetemen (három fővel),

- a Nyíregyházi Egyetemen,

- a DRHE Kölcsey Ferenc Tanítóképző Karán,

- a Partiumi Keresztény Egyetemen,

- a Babes-Bolyai Tudományegyetemen (Kolozsvár),

- a BBTE kézdivásárhelyi és sepsiszentgyörgyi kihelyezett tagozatain ugyanazzal a személlyel,

- a Munkácsi Állami Egyetemen,

- az Ungvári Állami Egyetemen,

- a Nagyváradi Állami Egyetemen,

- a II. Rákóczi Ferenc Kárpátaljai Magyar Főiskolán (Beregszász),

- a Sapientia Erdélyi Magyar Tudományegyetemen (Marosvásárhely),

- az Újvidéki Egyetem Magyar Tannyelvű Tanítóképző Karán (Szabadka),

- a Selye János Egyetemen (Révkomárom) (egy-egy fővel) magyar, angol és ukrán nyelven (1. ábra). 
Három interjúalany csak írásban vállalta a kérdések megválaszolását, a többi interjú hossza 40 és 80 perc közötti. Az írásban készült interjúk során, noha szűkszavú válaszokat kaptunk, ugyanakkor előny, hogy a konkrét kérdésekre válaszoltak, hiszen az interjúvázlat kérdéseihez írták megjegyzéseiket. Az interjúkban a következő kérdéskörök mentén vizsgáltuk meg az elméleti modelleket:

- Szervezeti környezeti tényezők (a testnevelés és sportolás szervezeti háttere, a sport célja, missziója; az intézményvezetés hozzáállása a sporthoz; sportkoncepció léte és célja; hallgatói szabadidős és versenysport; rendezvények, programok szervezeti háttere és céljai);

- Fizikai tényezők (infrastruktúra, felszerelés, fejlesztések, gazdasági tényezők);

- Személyi tényezők (testnevelő tanárok, óraadók szakmai jellemzői, feladatai, velük szemben támasztott elvárások);

- Konstruált környezeti tényezők (a hallgatók sportolási szokásainak és igényeinek mérése, a kapott adatok felhasználása).

1. ábra: A vizsgált intézmények földrajzi elhelyezkedése. Szerkesztette: Pallay Katalin

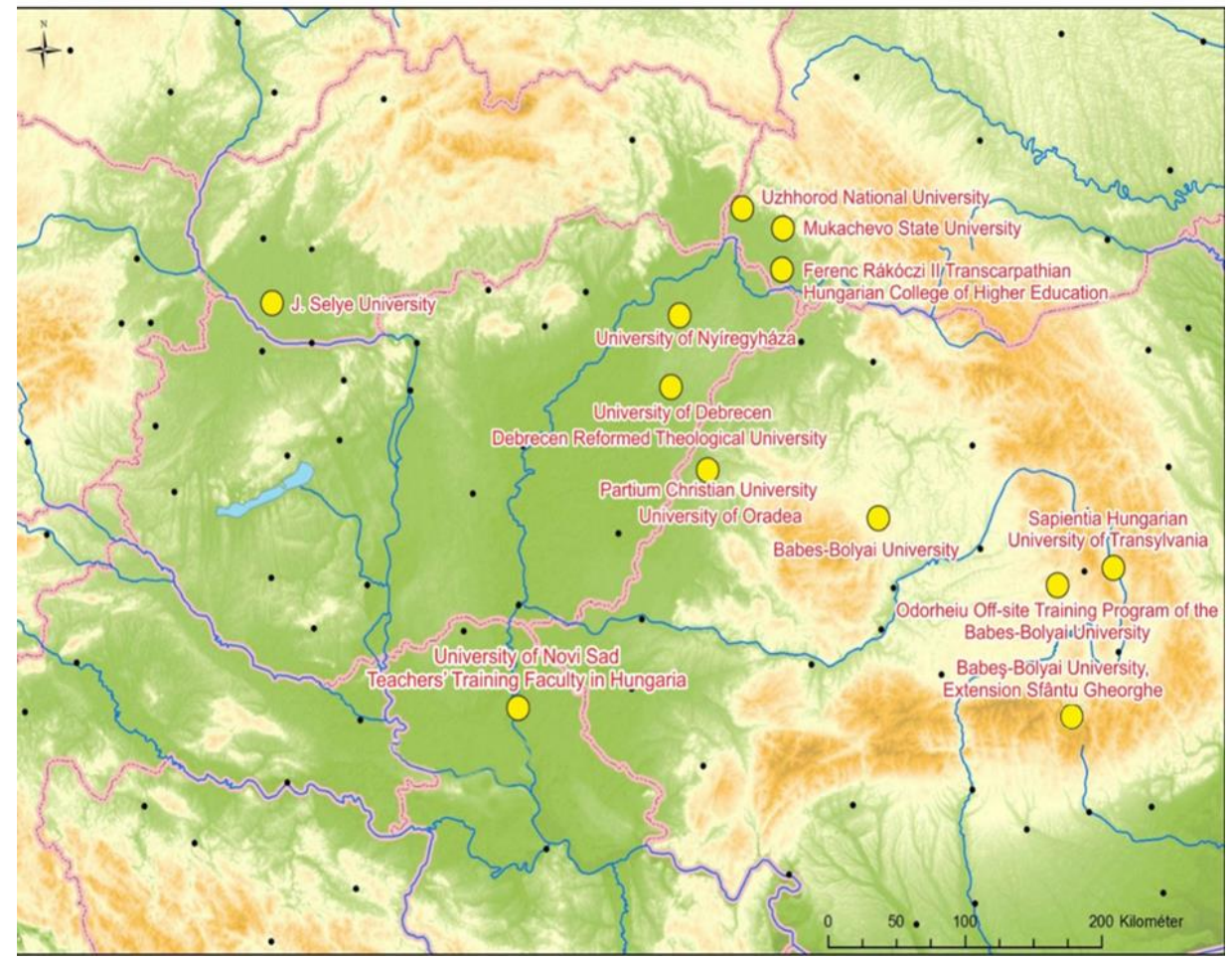


A vizsgált intézményeket négy típusba soroltuk a sporthoz való viszonyuk, a sportprogramok és versenysport szerepe, az intézményvezetés sporthoz való elköteleződése, a sport és testnevelés intézményben betöltött szerepe alapján: (1) versenyorientált, (2) a sport révén közösségteremtő, (3) testnevelés-fókuszú és (4) testkultúra-minimalizáló intézmények. Az első intézménytípusba azok az egyetemek kerültek, ahol a versenysportnak, sportolóknak, sporteredményeknek nagyon fontos szerepe van az intézmények életében, imázsában, sportkoncepciójában. Legtöbb esetben önálló egyesülettel és/vagy csapatokkal rendelkeznek, rendszeresen indulnak régiós, országos, akár nemzetközi versenyeken (ez egyébként más típusba tartozó intézményeknél is tapasztalható, akárcsak, az, hogy a közösségteremtő szabadidősport-rendezvényekre és a testnevelés szervezésére is komoly energiákat fordítanak, de a többiekhez képest a versenysport szerepe kiemelkedő az e csoportba tartozó egyetemek sportéletében). A közösségteremtő intézmények esetében a testnevelés órákat és a sporteseményeket, programokat elsősorban a hallgatói közösségek (újjá)építése, a hallgató-hallgató, hallgató-oktató kapcsolatok ápolása, javítása céljából szervezik, miközben fontos célként jelenik meg emellett az élethosszig tartó egészségtudatosságra való nevelés is a közös játék, élmények szerzése révén. A testnevelés-fókuszú intézmények kevesebb hangsúlyt fektetnek a sportrendezvények, programok szervezésére, fő profiljuk a kötelező testnevelés órák megszervezése és lebonyolítása az intézmény minden hallgatója számára (ami nagy egyetemek esetében önmagában is nagyon komoly szervezőmunkát igényel). Továbbá azon szakok esetében, ahol a kurrikulum tartalmaz mozgásos tevékenységekhez kapcsolódó kurzusokat, ezek szakmai (elméleti és gyakorlati) hátterét biztosítják, sőt legtöbb esetben nagyon komoly hangsúlyt fektetnek ezekre a képzésekre (testnevelés és sporttudományi, óvópedagógia és tanító szakok). A testkultúra-minimalizáló típusba tartozó intézmények életében egyáltalán nem jelenik meg a sport, a fő céljuk, hogy a kötelező minimumot, azaz a testnevelés órák megtartását teljesítsék. Tanulmányunkban azt vizsgáltuk meg, hogy az intézményi hatás egyes dimenzióit mérő modellek tényezői miként érvényesülnek ezekben az intézménytípusokban.

$\mathrm{Az}$ interjúkat a következőképpen elemeztük: a hanganyagok gépelt változatát az elméleti háttér négy dimenziójához kapcsolódóan kódoltuk, tehát első körben minden interjúban megkerestük a fizikai, szervezeti környezeti, emberi erőforrásra koncentráló modellekre és konstruált környezetre utaló interjúrészleteket, majd pedig ezeket vizsgálva az egyes dimenziókhoz aldimenziókat/alkódokat rendeltünk. A fizikai környezeti tényezők 
alkódjai a következők voltak: infrastrukturális háttér és annak minősége, felszereltsége, külső infrastruktúra igénybevétele, sporttudományi háttér, jövőbeli infrastrukturális fejlesztésekre való törekvés. A szervezeti környezeti tényezők kódjai: a testnevelés jogszabályi háttere, a testnevelés szervezése (intézeti szint) - strukturális keret, a sport szervezése - strukturális keret, emberi erőforrás - személyi keret, policy keret (intézményvezetők hozzáállása, céljai), szimbolikus keret (sport/testnevelés célja, értéke, missziója, küldetéstudat), intézményi kultúra - kampusz miliő, a szabadidő- és a versenysport intézményi jellemzői. Az emberi erőforrás alkódjai: testnevelő tanárok, óraadók szakmai jellemzői, feladatai, velük szemben megfogalmazott elvárások, a szabadidős sportrendezvények és testnevelés szervezésének személyi háttere, hallgatói attitűdök. Konstruált környezet alkódjai: a sport illetve testnevelés célja funkciója, a testnevelés elismertsége az intézményen belül, a hallgatók sportolási szokásainak, igényeinek vizsgálata, az oktatók és a hallgatók kommunikációja, a versenysport és sportolók támogatottsága az intézményen belül, a versenysport elismertsége, felépítése.

$\mathrm{Az}$ elemzések harmadik lépéseként ezekben dimenziókban és aldimenziókban végeztünk összehasonlítások az intézménytípusok között. Az egyes aldimenziók összefüggéseinek, átfedéseinek és a kapcsolatok azonosítása intézménytípusonként Atlas.ti program segítségével valósult meg. Feltáró vizsgálatról lévén szó a legfontosabb cél a modellek alkalmazhatóságának tesztelése volt, nem pedig egy általános tipológia létrehozása, így a kapott eredmények nem általánosíthatók, csupán a vizsgált intézményekre érvényesek, ahogy a tipológia is.

\section{A kutatás eredményei}

A kutatás eredményeit a vizsgált modellek mentén mutatjuk be. Külön térünk ki a fizikai, szervezeti környezeti, emberi erőforrásra koncentráló és konstruktív környezeti modellekre, tényezőkre a vizsgált intézmények sportéletére vonatkozóan, melybe egyaránt beletartoznak a sportprogramok, események, rendezvények és a testnevelés kérdésköre is.

\section{A fizikai környezet különbségei az egyes intézménytípusokban}

Jelen alfejezetünkben a sportolás fizikai környezetének különbségeit vizsgáljuk az egyes általunk meghatározott intézménytípusokban. Legfőbb célunk annak a felmérése, hogy az intézménytípusok között milyen különbségek fedezhetők fel a sportolás fizikai környezetét tekintve, milyen hangsúlyt fektetnek az egyes intézmények arra, hogy a jövőben esetleg 
további infrastrukturális fejlesztéseket célozzanak meg a sportolási lehetőségek javítása érdekében, mennyire jelenik meg ez célként.

A kutatás elméleti hátterében részletesen kifejtettük a sportolás fizikai környezetének hatása kapcsán: minél inkább támogató a fizikai környezet egy helyi közösségben, mindemellett hozzáférhetők, megfizethetők, civilizáltak és biztonságosak az egyes sportlétesítmények, annál inkább valószínűsíthető, hogy egy ott lakó egyén is fizikailag aktív lesz (Sallis et al., 2009; Pan et al., 2009; Bácsné Bába et al., 2018). Majdnem minden intézményben megjelenik a kötelező testnevelés tantárgy, ami miatt alapvető intézményi háttérrel (mint például a tornaterem) többségében rendelkeznek az intézmények. Ugyanakkor mégis találkozhatunk több olyan intézménnyel is, amelyben jelenleg még nincs használható tornaterem, de folyamatban van annak a felújítása vagy megépítése. Az interjúk elemzését követően látható, hogy azokban az intézményekben tűnik erősebbnek a mozgáshoz kapcsolódó infrastrukturális háttér, ahol a sportolásra és a sporttudományi képzésre egyaránt kiemelt figyelmet szentelnek, vagy ahol évek óta folyamatosak a sportcélokra irányuló fejlesztések.

A versenysport-orientált intézményekben mindez jól láthatóan prioritást élvez, az általunk megkérdezett interjúalanyok véleménye szerint ugyanis kiemelt szerepe van az egyetemeken tanuló hallgatók sportolási szokásaihoz illeszkedő megfelelő fizikai környezet kialakításának és az ehhez kapcsolódó sporttudományi háttér biztosításának. Mindezt az is kellően alátámasztja, hogy az ilyen típusú intézmények sportolási lehetőségei szélesebb palettán mozognak, illetve általában több bázison valósulnak meg. Az ilyen intézmények céljai között szerepel többek között az is, hogy a kikapcsolódni vágyóknak szintén megfelelő feltételeket biztosítsanak. Az intézményekre jellemző még a folyamatos fejlesztés és fejlődés is, tehát igyekeznek minél körültekintőbben felmérni és ezek alapján kielégíteni a sportolni vágyó egyetemisták igényeit. Mindez bázisbővüléssel, új sportágak bevonásával érhető el a legkönnyebben, amelyeket ezek az intézmények előszeretettel alkalmaznak. Az egyik ilyen egyetem esetében például strandfoci, müfüves és teniszpályák vannak épülőben, sőt többségében már meg is épültek, az egyetem több kampuszán is, amelyek mindenképpen bővíthetik az ezeket a sportágakat űzők lehetőségeit. Ugyanakkor ezzel szemben érdekes, hogy némely ilyen típusú intézménynek is szüksége van esetenként külső infrastruktúra igénybevételére azon sportágak érdekében, amelyeket saját infrastrukturális bázisból alapvetően nem lennének képesek megvalósítani, ilyen például a sízés vagy az úszás. 
A sport révén közösségteremtő intézmények esetében már más a helyzet. Ezen intézmények többsége korántsem rendelkezik olyan mértékű és minőségú infrastruktúrával, mint azt az előbbi kategóriában láthattuk. Legfőbb feladatuk a sport általi közösségteremtés, ezáltal nem mindenhol rendelkeznek sportegyesülettel, valahol testnevelési intézettel, tanszékkel sem, ahol mégis van, az is alapszinten múködik. Ezzel szoros összefüggésben az infrastrukturális ellátottság is szerényebb szinteken múködik. Egyes helyeken meglennének ugyan a feltételek, ugyanakkor több jövőbeli felújításra is szükség van a megfelelő múködés elérésének érdekében.

Nemcsak az infrastrukturális bázisok szorulnak ezen intézmények esetében fejlesztésre vagy korszerúsítésre, hanem a rendelkezésre álló eszközök is. Több esetben elmondták az interjúalanyok, hogy hiába vannak meg a sportszerek, sporteszközök egy-egy intézmény bázisában, ha azok jelenlegi állapotukban alig használhatóak és javításra szorulnának. Ezen intézmények többsége nem rendelkezik sporttudományi képzéssel, illetve nem minden esetben szorulnak külső infrastrukturális segítségre sem, hiszen azt az adott mennyiségű hallgatói csoportot kényelmesen tudják oktatni az ottani háttér segítségével is, viszont merészebb célok kitúzése esetén (pl. sporttudományi képzés és/vagy a versenysport beindítása) már korántsem biztos, hogy a meglévő infrastruktúra elegendő lenne.

A testnevelés-fókuszú intézmények esetében szintén más tapasztalatokat szerezhettünk a kérdéskör vizsgálatát követően. Ezen intézmények esetében leginkább a testnevelés órák megszervezése és lebonyolítása van a fókuszban, mindezen célok pedig hatással vannak az infrastrukturális háttérbázisukra is. Az ebbe a csoportba sorolt intézmények között találkozhatunk olyanokkal, amelyek rendelkeznek saját sportközponttal, az egyik ilyen esetében például aerobic-és fitnesztermet hoztak létre a sportolni vágyók számára. Mindemellett az itteni intézmények számára mégsem prioritás a sportolási lehetőségek fejlesztése, hiszen elsődleges célként a már korábban leírtakat igyekeznek megvalósítani. Mindezt jól mutatja, hogy például az egyik tanítóképző karon a legfontosabb célként a hallgatók megfelelő körülmények közötti testnevelés oktatását jelölték meg, így ennek a javítása áll jelenleg az élen a kar sportolás érdekében tervezett fejlesztései között. Van olyan intézmény is, aminek az általunk megkérdezett interjúalanya szerint szüksége lenne ugyan egy sportcsarnokra, de mindez egyelőre nem szerepel az egyetem elsődleges beruházási tervei között. Azt láthatjuk tehát összességében, hogy több esetben sem feltétlen a sportolással, testneveléssel foglalkozó, kompetens személyek döntésén vagy észrevételein 
múlnak a sporttal kapcsolatos infrastrukturális fejlesztések, hanem egész egyszerúen az adott egyetem tervei között nem szerepelnek egyelöre az ilyesfajta célok.

A testkultúra-minimalizáló intézményekben rendkívül kevés szerep jut a sportnak, fő céljuk a kötelező testnevelés órák lebonyolítása, ezzel összefüggésben pedig csupán minimális infrastrukturális hátteret igényelnek az órák megtartásához. Az egyik ilyen egyetemi karon az interjúalanyunktól az ottani tornaterem felszereltségéről érdeklődtünk és a következő választ kaptuk: „Egy 15 méter hosszú nagyobb terem, semmi igazából, van egy betonozott udvar, az is tele van gödrökkel, nagyon gyenge. Nem értem, most újitották fel ezt az iskolát, és a tornapályát nem tudták megcsinálni." (Testkultúra-minimalizáló intézmény1) Interjúalanyunk az interjú további részében is kifejtette elégedetlenségét az egyetemük sportolással kapcsolatos infrastrukturális hátterével kapcsolatban, mivel szerinte mind a gimnazistáknak, mind pedig az egyetemistáknak sokkal korszerúbb és bőségesebb sportolási lehetőségeket biztosító fizikai környezetre lenne szükségük. Nem csoda tehát, hogy ezen intézmények esetében is szükség van a külső infrastruktúra igénybevételére, valamelyest javítva ezzel a hallgatók sportolási lehetőségeit. Egy másik intézmény esetében saját tornaterem sem található meg az egyetemen belül, így azt nekik bérelni szükséges az egyik közelben lévő középiskolától. Mindezen tények tehát jól mutatják, hogy ezekben az intézményekben nemhogy a sportolás, hanem maga a kötelező testnevelés órák lebonyolítása is rendkívül körülményes, így ebben az esetben az egyetemistáknak igen kevés lehetősége van arra, hogy esetleg délutánonként sportolhassanak az egyetem keretein belül.

\section{A felsőoktatási sport és testnevelés szervezeti környezeti valamint személyi tényezői}

Schein (2010) három szintet fogalmaz meg a szervezeti kultúra értelmezésében: 1. struktúrák és folyamatok, 2. normák és értékek és 3. alapvető mögöttes feltételezések. A szervezeti kultúra kutatások mentén Chatman \& O’Reilly (2016) vizsgálataik alapján arra a következtetésre jutottak, miszerint a Schein-féle meghatározás középső szintjéből kiindulva a kutatások során a normákat kellene a középpontba helyezni. A normák egy meghatározott közösséget, vagy szervezetet jellemeznek és amelyek, ha eléggé elterjedtek és erősen kötődnek hozzá, akkor akár a tagok attitűdjét és viselkedését befolyásoló társadalmi útmutatóként is működhetnek. A definíció szempontjából a normákat három rétegben értelmezhetjük: a tartalom (az adott közösség mit tart fontosnak), konszenzus (annak a mértéke, hogy a norma mennyire elterjedt és elfogadott), valamint az intenzitás (érzelmek a 
norma kapcsán, például képesek-e a norma betartása érdekében szabályokkal irányítani másokat). Hasonló érték- és normarendszerek mentén kutatnak a szervezeti környezeti modellek, amelyek leginkább arra a kérdésre keresik a választ, hogy milyen szervezeti rendszer, értékek, küldetéstudat, policy, szimbólumok alkotják és határozzák meg a sportéletet (Kezar, 2017). Kutatásunkban azt vizsgáltuk meg, hogy milyen strukturális keretei vannak a testnevelés és sport szervezésének (strukturális keret), milyen küldetése, missziója és értéke van ezeknek az intézmények életében, önmagáról közvetített képében (szimbolikus keret), ezáltal milyen intézményi kultúra és kampuszmiliő alakul ki, ami körülveszi és meghatározza a hallgatók sportszocializációját. Továbbá azt is megnéztük, hogy az intézményvezetés és a sportban, testnevelésben résztvevő személyek hogyan alakítják ezt a sportos vagy kevésbé sportos intézményi kultúrát (policy és emberi erőforrás/személyi keret). Mivel az intézményi kultúra szerves része az azt működtető személyek hozzáállása, értékei, magatartása, ezért ebben a fejezetben a szervezeti környezettel együtt tárgyaljuk a személyi tényezőket is az emberi erőforrás modellekhez kapcsolódóan. Összehasonlító vizsgálatunk fő kérdése, hogy ezekben a kérdéskörökben milyen különbségeket és hasonlóságokat fedezhetünk fel az egyes intézménytípusok között.

A testnevelés strukturális kereteit alapvetően két fontos tényező határozza meg: a jogszabályi háttér (milyen kötelezettségeik vannak a hallgatóknak), ez pedig országonként változó, illetve az, hogy milyen infrastrukturális lehetőségei vannak az intézménynek. Azt láthatjuk, hogy mind a négy országban alapvetően a felsőoktatási intézmény hatáskörébe tartozik, hogy milyen testneveléshez köthető kötelezettségeket kell teljesíteni a diákoknak, ez lehet kreditalapú (PI. PKE) vagy kritériumkövetelmény (DE, NYE, SJE, II. RFKMF, MÁE stb.). Minden általunk vizsgált intézményben megjelenik a kötelező testnevelés valamilyen formában, azonban más és más céllal. A versenyorientált intézményekben legalább olyan hangsúlyt fektetnek erre, mint a versenysportra, sőt találhatunk példát arra is, hogy ez ad keretet a versenyzők kiválasztásához, vagy a közösségépítéshez az ilyen típusú intézmények esetében is. A testnevelés órák további célja, hogy érdekeltté tegyék a hallgatókat a szabadidős sportprogramokban, alkalmat adva arra, hogy újabb és újabb élményeket szerezzenek a sportolás által, ami hozzájárulhat az élethosszig tartó sportszocializációjukhoz. A testnevelés-fókuszú intézményekben természetesen ez alkotja a sportélet legfontosabb pillérét. Alapvetően a testnevelési tanszékek, intézetek két feladatot látnak el: ők szervezik 
meg, hogy minden hallgató lehetőségeinek, igényeinek és időbeosztásának megfelelően tudja teljesíteni a testnevelés-kötelezettséget, illetve gyakorlati és elméleti órákat tartanak azokon a képzéseken, ahol a képzési tervben megjelennek a motorikus képességekhez kapcsolódó tantárgyak. Ezekból a testnevelés órákból nőttek ki aztán az olyan szakkörök, sportfoglalkozások, amik már nem kötelező jellegűek, hanem a lelkes hallgatók sportolási igényeit elégítik ki az intézmény falain belül. A verseny- és testnevelés-fókuszú intézményeknél fontos szervezési kritériumként jelenik meg, hogy minél szélesebb választási lehetőséget kínáljanak a hallgatóknak, és/vagy az órák minél élménydúsabbak, játékosabbak legyenek, amennyiben a fizikai lehetőségek nem teszik lehetővé több sportág felkínálását. A közösségteremtő intézményekben, akárcsak egyes versenysport-orientált egyetemeken is, pedig a legfontosabb cél, hogy olyan szakok hallgatói is találkozzanak, s részt vehessenek közös, s emellett egészséges tevékenységben, akik egyébként aligha találkoznának, pláne nem alkotnának közösséget. A fő cél egyébként mindenhol a mozgás megszerettetése és fontosságának felismertetése az egészségtudatosság szempontjából, ezáltal az élethosszig tartó egészségtudatos életmódra történő nevelés. A testkultúra-minimalizáló intézményekben tulajdonképpen egy személyre, a testnevelő tanárra hárul a testnevelés órák megszervezése és lebonyolítása, s ez képezi az intézmények teljes sporthoz kapcsolódó tevékenységét (más sportprogramok infrastruktúra és intézményi háttér, koncepció, elköteleződés hiányában szinte egyáltalán nincsenek).

... [célunk] „Egy olyan közösséget igyekszünk kovácsolni, és ez majd a programoknál fog előjönni ismételten, hogy a mozgás által jobban megismerik a hallgatók egymást, illetve a pedagógusok is a hallgatókat. Tehát tényleg egyfajta közösségformáló szerepet szeretném, hogy betöltsön ez a mozgás az intézményben, illetve a testnevelés. Igazi cél egyébként eredményességi szempontból nincs, tehát nem eredmény, hanem inkább az emocionális érzéseket szeretnénk kielégíteni a hallgatók körében... Míg a teológusoknál, ahogy mondtam elsősorban kondicionális, mert amit tapasztaltunk az elmúlt két évben, hogy sajnos mind állóképesség, mind erő, a gyorsaságot nem is veszem bele, el vannak maradva ezek a hallgatók. És ezeket próbáljuk egy kicsit, amíg van lehetőségünk, egy kicsit formálni." (Közösség-formáló intézmény1)

Nagyon fontos, hogy a testnevelés órák, csak abban az esetben érik el fő céljukat, ha ezeken az órákon való részvétel valamilyen módon kötelező (szükséges feltétel a diplomaszerzéshez). Az ÚE szabadkai karán kötelezően választható tárgyként kell teljesíteni 
vagy testnevelést vagy énekkart, míg a beregszászi főiskolán minden félévben kötelező egy szakkörön részt venni (a kilenc választhatóból hat sportfoglalkozás). Ennek a külső motívumnak a hiányában azonban a hallgatók jelentős részére az jellemző, hogy amint megtudják, hogy semmilyen következménye nincs annak, ha nem járnak be testnevelés órára, a továbbiakban nem fognak járni. Így van ez az egyik versenysport-orientált egyetemen:

„Nálunk van 3 csoport a testnevelésnél, 1. általános csoport, akik bármilyen szakra járnak, ők egyszer járnak testnevelö órára hetente. Ez nekik kötelező. De a diplomához nem kötelező. Ez is kb. 50\%- os látogatottságú. Az első szemeszterben jobban járnak, mert még nem tudják, hogy nincs formális kontrol. De szünidő után valahogy megtudják, hogy ez nem fog számítani az osztályozáskor. Ekkor már csak 25\%-uk jár. A második szemeszter katasztrofális, 25 \%-os látogatottság. A második csoport a speciális egészségügyi csoport, itt vannak jó speciális kollégáink, akik a betegség, és egészségmegőrzést betegségcsoportonként is felosztják, 3 nagy csoportra. De sajnos ez sem kredites. És a 3. csoport, a sport csoport, akik háromszor hetente járnak, ők versenyeznek, válogatottak. Járnak egész Ukrajna területén, futsalt játszanak. 360-an vannak a sportcsoportban." (Versenysport-orientált intézmény1)

Az intézmények sportjának strukturális feltételeit elsősorban nem az határozza és különbözteti meg egymástól, hogy milyen típusba tartoznak, hanem hogy milyen nagy hallgatói létszámú intézményről van szó, illetve országonként találunk különbségeket, amelyek felülírják a típusbelieket. A majdnem 30 ezer hallgatót számláló Debreceni Egyetem komplex sportéletének irányítására 2015-ben jött létre a Sporttudományi Koordinációs Intézet, melynek „Feladata az egyetemen folyó, illetve az egyetemmel kapcsolatos sporttevékenységek összefogása, müködtetése, a sporttudományi oktatás karokon való fejlesztésének segítése, koordinációja, a sporttudományi kooperativ kutatások elösegítése, a témához illeszkedő intézményen belüli és intézményközi kapcsolatok fejlesztése, valamint részvétel a debreceni sportegészségügyi diagnosztikai, ellátó és rehabilitációs rendszer kialakitásában és müködtetésében." ${ }^{2}$

A Magyar Egyetemi és Főiskolai Sportszövetség egy korábbi pályázata révén jöttek létre nagyobb magyarországi intézményekben sportirodák, így múködik jelen esetben a DE-n és az NYE-n szoros együttmúködésben a HÖK-kel és testnevelési tanszékekkel, intézetekkel. Az utóbbi esetben a HÖK által szervezett sportprogramok megjelennek az egyetem által

\footnotetext{
${ }^{2}$ Forrás: https://sportsci.unideb.hu/bemutatkozas
} 
szervezett hallgatói fesztiválon (FŐHE). A két intézmény(típus) között a legfontosabb különbség, hogy míg a DE-n a Sportiroda a sportszervezeti rendszer fontos egyedi intézeteként funkcionál önálló feladatokkal, sajátos szereppel az intézmény életében, addig az NYE-en fennmaradása és múködése pályázati források elnyerésétől függ. Hasonlóképpen a szabadkai MTTK-n a HÖK együttmúködik az egyetem és a városban múködő más intézmények HÖK-jeivel a sportprogramok terén. A sportiroda fő feladata az egyik versenysport-orientált intézményben:

„A fö feladata, amikor elindult, az volt, hogy ami nincs, azt csináljuk. A kommunikáció, a marketing rész, illetve természetesen szabadidősport-rendezvények szervezése, ami akár szabadidős bajnokságok, kupák. De természetesen itt van ingyenjegy programunktól kezdve, nagyon sok kedvezményes jegyalap. Tulajdonképpen a sportot népszerüsítjük a hallgatóknál, vagy sportolás formájában, akár testnevelés, versenysportban segítünk, elég nagy területet. Illetve itt az együttmüködő partnerek, akár a ... kézi, focicsapata, a vízilabdázóknak, jégkorongozóknak, ingyenes vagy kedvezményes jeggyel is szeretnénk a sportot népszerüsíteni." (Versenysport-orientált intézmény2)

A beregszászi főiskola vezetése és testnevelői egyedi módon népszerűsítik és szervezik a sportot, s teszik a közösségépítés egyik formájává: kilenc szakkör közül, melyből hat valamilyen sportághoz kapcsolódik, kell teljesíteni minden szemeszterben egyet (a szakkörvezető aláírásával) a diplomaszerzéshez. Ezek közül nagy népszerűségnek örvendenek a sportszakkörök (kézilabda, kosárlabda, röplabda, asztalitenisz, futball, aerobik), amelyek egyben a versenycsapatok kialakulásának és a már létező csapatokba való bekapcsolódás lehetőségét is jelentik.

A személyi tényezőket vizsgálva azt láthatjuk, hogy egészen más szerep jut a testnevelőknek azokban az intézményekben, ahol van szervezeti háttér (sportiroda, tanszék, intézet) a testnevelés és sport mögött, mint azokban, ahol tulajdonképpen egy-két-három lelkes oktató kezében van a testnevelés és sport szervezése. A versenysport-orientált intézményekben fontos elvárásként fogalmazódik meg, hogy az órákon, sportfoglalkozásokon is képviselnie kell az oktatónak azt a missziót, amit az egyetem is megfogalmazott, hírnevéhez, küldetéstudatához és identitásához méltó magas szintű szakmaiságot, figyelmet a hallgatók igényeire, kérdéseire vonatkozóan, amiben az esetleges órán kívüli sporttevékenységre történő motiválás, tehetség-kiválasztás is szerepet kap. Szintén jellemző, hogy a tanárok egy 
része maga is versenysportoló (volt), illetve edzőként funkcionál még az egyetem falain belül, esetleg kívül is.

„Amit mi elvárunk, az, hogy a ... Egyetem imázsához, arculatához, és szándékához mérten, közvetítsék ök is a sport, és testnevelés irányába az elkötelezettségüket." (Versenysport-orientált intézmény2)

A közösség- és testnevelésóra-fókuszú intézményekben az oktatók szerepe kulcsfontosságú, hogy elérjék a sportprogramok és a testnevelés órák céljait: olyan közösség létrehozása a sport révén, ahol vidám hangulatú programokon jól érzik magukat a hallgatók, megismerkednek egymással, s közösséggé kovácsolódnak össze a különböző szakos diákok, illetve olyan magas szintű szakmai munkával szervezett testnevelés órák, ahol valóban fejlődnek a résztvevők fizikailag, mentálisan és szaktól függően szakmailag is. Ehhez mindkét esetben fontos közvetlen kapcsolatban lenni a hallgatókkal, meghallgatni igényeiket, alkalmazkodni órarendjükhöz és elvárásaikhoz. Azonban pl. a szabadkai karon az oktatási tevékenységen túl nagyon komoly (egészség)nevelői munka is zajlik a diákok egészségtudatos életmódra való nevelése céljából, hiszen a testneveléshez kapcsolódó órákat vezető oktatók találkoznak egyedüliként az intézményben minden egyes hallgatóval, akik a karon tanulnak. $A z$ ő felelősségük nagy abból a szempontból, hogy nemcsak pótolják az iskolai sportszocializáció, motorikus képességbeli deficitet, küzdenek a mozgással szembeni alapvető negatív attitűdökkel, hanem egy olyan generációt engednek el évről évre diplomával a kezükben, akik számára nemcsak saját egészsége, hanem az óvodások és kisiskolások egészségtudata, a mozgás megszerettetése is fontos kell, hogy legyen.

„...gyakran találkozom diákokkal fitneszterembe, ahová én is rendszeresen eljárok, a tevékenységeket itt én vezetem, tehát azt mondom a 20 éves fiatalnak, hogy kérlek, tartsd a ritmust velem és ez nagyon sokat számít neki, mert azt mondja, hogy ha ő is mozog, akkor majd ő is az én koromban is fogja tudni tartani a ritmust a fiatallal. És egyáltalán a hozzáállásom, a lelkesedésem nekem hatalmas és ezt igyekszem nekik átadni. A mozgás szeretetét..." (Közösségteremtő intézmény2).

„Van egy tantárgyunk, az a neve, hogy mozgásos játékok... És végigjátsszák a 1,5 órát. És akkor döbbennek rá, hogy mi az, amiböl kimaradtak. Mekkora pluszt ad ez az életükhöz. 20 évesek szaladgálnak, mint a kisgyerekek. Így próbálom megfogni öket, hogy amit megtapasztalnak, vigyék be az életükbe. És amikor majd tanítók, vagy pedagógusok lesznek, ezt a szemléletet vigyék tovább. Tisztában vagyok, hogy ez utópisztikus, de jobb, mint a 
poroszos rendszer... Mi tanárokként ezt tudjuk hozzáadni, hogy lehetőségeket kínálunk. Valószínü, hogy valami megragadja őket" (Testnevelés-fókuszú intézmény2).

A testkultúra-minimalizáló intézményekben egy személy küzd nap mint nap az intézménnyel és a hallgatókkal is a testnevelés fontosságának és a lehetőségek fejlesztésének érdekében. Ők - akárcsak egyes közösségteremtő intézményekben - példaként szolgálnak a hallgatók számára, hogy miért fontos mozogni, így lelkesedésük, kitartásuk és lelkiismeretes munkájuknak köszönhető, hogy egyáltalán van valamilyen mozgásos tevékenység az intézményben (azon túl, hogy kötelező testnevelést tartani a jogszabály szerint), s ennek értelme és funkciója is legyen.

„Én vagyok az egyetlen óraadó tanár és ennek is gazdasági okai vannak, mert sokkal kisebb a fizetés, mint a középiskolában és az egyetem a szükre szabott keret miatt nem is tud többet, tehát inkább szerelemből dolgozom. Már ez is illusztrálja, hogy az én életfelfogásomban mennyire fontos a mozgás. Óraadóként dolgozom, több, mint 10 évig föállásban voltam, de le kellett sajnos mondanom az anyagi tényezők miatt, de ez nem jelenti azt, hogy nem fontos és fö problémaként kezelem ezt a problémát, mert az ember, amit szeret azt csak teljes részvétellel, 100 \%-os bedobással tudja csinálni és én szeretem a mozgást, szeretem a fiatalokat, szeretek nevelni, szeretem, amit csinálok, azt 100 \%-osan elvégezni, legalább is ezt célzom meg mindig..." (Közösségteremtő intézmény2).

A policy keret vizsgálatakor egyértelmúen kirajzolódik az intézményvezetés, mint következő személyi tényező hozzáállásának, elköteleződésének vagy ennek hiányának szerepe és hatása az intézmények sportéletére. A versenyorientált egyetemeken, de máshol is, ahol vannak egyetemi színekben versenysportolók, az intézmény beépíti a sportsikereket az egyetem imázsába, ezzel is vonzóbbá téve magát a jelenlegi és leendő hallgatók számára. Fontos megemlíteni, hogy nem elég a legfelsőbb vezetők (pl. rektor vagy kancellár elköteleződése) ahhoz, hogy minden hallgatóhoz eljusson a sportolás fontossága, vagy éppen minden sportoló hallgató megbecsülést és támogatást kapjon tanulmányaihoz, mezo, azaz kari szinten szükséges a támogatás a dékánok részéről. A közösség- és testnevelés óra fókuszú intézményekben az anyagi lehetőségektől függően az infrastruktúra és tárgyi eszközök, ezek hiányában pedig külső intézményekkel való kooperálás révén kedvezmények biztosítását fogalmazza meg a vezetés fő feladatául. Emellett megjelennek összefonódások az intézményés kisebbségpolitika sajátos szegmenseivel: azokban a határon túli intézményekben, amelyek sportinfrastruktúrája anyaországi támogatással (is) jött lére, ott a versenysport- 
eredményekkel és múködő programokkal igyekeznek meghálálni a segítséget, az Újvidéki Egyetem sportszervezete pedig folyamatosan lobbizik a mindenki számára kötelező testnevelés bevezetésért. A testkultúra-minimalizáló intézmények esetében egyértelmúen látszik annak következménye, ha a vezetőség nem tartja fontosnak a sport bármilyen formáját:

„Tehát én úgy gondolom, hogy mivel kötelező a testnevelés, beteszik, de nem azért teszik be, jó, nem akarom őket bírálni. Azért teszik be, mert kötelező, maradjunk ennyiben... a sport az egy kötelező dolog az egyetemen, és ezt a minimális egy órát tartsd meg, de több nem érdekli őket" (Testkultúra-minimalizáló intézmény1).

A szimbolikus keretet vizsgálva azt néztük meg, hogy milyen küldetése, missziója, értéke és célja van a sportnak és testnevelésnek a vizsgált intézményekben. A testnevelés céljáról és összehasonlításáról intézménytípusonként már fentebb volt szó, de a sportprogramokra, rendezvényekre vonatkozóan is elmondható, hogy ezek fő célja minden intézményben a mozgás, a sport megszerettetése, fontosságának tudatosítása az egészséges életmód viszonylatában, pozitív élmények nyújtása, a közösségformálás. Az egyes intézménytípusok között elsősorban tartalmi különbségek vannak, melyeket meghatároznak természetesen az infrastrukturális, anyagi lehetőségek, s mint fentebb láthattuk, az intézményvezetés attitűdje. A versenysport-orientált intézmények sajátossága a komplex gondolkodás: egyaránt fontos hangsúlyt fektetnek a változatos, érdekes testnevelés órák biztosítására, a hallgatóközpontú sportrendezvényekre, melyek esetenként a versenysport alapját (versenyzők kiválasztását) képezik, de emellett a versenysportolók és egyetemi csapatok megjelennek az intézmények önmagukról alkotott és kifelé mutató képében. Rendszeresen bemutatják, és kellő nyilvánosságot adnak a versenysportolók eredményeinek, díjazzák őket, s ennek kettős funkciója van: a világ felé büszkén mutatják, hogy ezek a sportolók is az adott egyetemet választották, illetve azt, hogy milyen eredményesek az egyetemi sportoló csapatok, a saját hallgatók felé pedig azt közvetítik, hogy érdemes és lehetséges hallgatóként sportolni, s az intézmény megbecsüli sportoló diákjait, példaként állítja őket a többi hallgató elé.

„Még azt szeretném mondani, hogy a mi karunkon szoktunk találkozókat rendezni a régi hallgatókkal, akik sportmesterek, vagy nemzetközi sportmester címmel rendelkeznek. Eljönnek, és találkoznak az elsősökkel, másodikosokkal, elmesélik, hogy hogyan tanultak, edzettek, versenyeztek. Kb. fél évvel ezelött volt egy olimpián induló sportoló, a mi 
hallgatóinkkal találkozott. Elmondta, hogy milyen fontos a tanulás és a testnevelés" (Versenysport-orientált intézmény1).

A közösségformáló intézményekben nagyon fontos a személyes kapcsolat kialakítása a résztvevőkkel és egymás között, a sportos tevékenység csak így éri el valódi funkcióját: nagyon fontos, hogy a tanár megismerje a résztvevők igényeit, korábbi tapasztalatait, elvárásait, s esetleges problémáit, rendszeresen kommunikáljanak egymással, ez pedig csak úgy lehetséges, ha az órák után és között személyes beszélgetésekre kerül sor. A testnevelésórafókuszú intézményekben egyrészt bizonyos nehézségek miatt nincs lehetőség nagyobb sportéletre, másrészt az iskolai testnevelés óra hiányosságai, vagy éppen a képzési sajátosságok miatt van szükség nagyobb hangsúlyt fektetni a testnevelés órák szervezésére, tartalmára, hogy megismerhessenek olyan sportágakat, mozgásformákat, s így olyan sporttal kapcsolatos élményeket szerezhessenek, amikre korábban nem is volt lehetőség. Sok esetben azt láthatjuk, hogy itt zajlik a rendszeres fizikai aktivitásra történő nevelés és a negatív attitűdök lebontása a mozgással kapcsolatban:

„Pont most volt TRX edzés! Az elején mindenki azt mondta, hogy nem tudom végigcsinálni. Utána átbillentek, végig csinálták, és örültek, hogy ilyenben részt vehettek. És köszönik a karnak, hogy volt ilyen lehetöség, mert korábban ilyen mozgásformával nem találkoztak... A lényeg az, hogy nem tudod elképzelni a boldogságot az arcukon a gyakorlatok közben" (Testnevelés-fókuszú intézmény2).

A sportra vonatkozó intézményi kultúra, kampusz miliő nem választható el a fent bemutatott szimbolikus kerettől, de itt kell megemlítenünk és elemeznünk az intézményi sportkoncepciót (amennyiben van ilyen). A versenysport-orientált intézményekben találunk ilyet, vagy ha nincs is egy konkrét dokumentumban megfogalmazva, akkor minden évben össze kell állítani a vezetőség számára, hogy milyen testneveléshez és sporthoz kapcsolódó céljaik, feladataik és terveik vannak a sportot szervező intézetnek. A többi intézménytípusban nem jelenik meg ennyire konkrétan a sportkoncepció az intézményi kultúrában, azonban a testnevelést szervező intézetek, vagy testnevelők küldetéstudatában mindenképpen érezhetjük, hogy a legfontosabb cél a sport megszerettetése, beépítése a mindennapjaikba és a pályájukba pedagógus-jelöltek esetében. Az egyik versenysport-orientált egyetem sportkoncepciója egyedülálló komplexitását, kiemelkedő szakmaiságát tekintve:

„Számba vettük, hogy ehhez milyen célrendszert kell felállítani, testnevelés, sporttudományi oktatás beindítása, infrastruktúra, sportegészségügy, versenysport stb. És 
akkor ehhez hozzávettük, hogy a cél megvalósításához, milyen tevékenységek milyen feladatok szükségesek, ezt ki végezze el, és honnan lesz rá pénz. És most 12 évvel ez után, elmondhatjuk, hogy nagyon sok eredményt elértünk már, de hála Istennek nem teljesítettük a táblázatunkat, úgyhogy, van még hova fejlödni. Ennek a keretében kezdtük el, hogy a személyi állomány fejlődjön, az infrastruktúra fejlödjön, kutatások legyenek az egyetemen, és mindegyik vonalon szépen haladtunk" (Versenysport-orientált intézmény2).

\section{A konstruált környezeti tényezők vizsgálata az egyes intézménytípusokban}

A konstruált környezeti modell vizsgálata során, arra kerestük a választ, hogy az intézmények miképpen szereznek információt a hallgatók sportolási szokásairól, illetve hogyan tudják erre reagálva kiszolgálni a hallgatók sportolási igényeit. Továbbá kíváncsiak voltunk arra, hogy a megkérdezett interjúalanyaink miként látják a hallgatók sporthoz való hozzáállását illetve kötődését.

Egyértelműen a legkönnyebb dolga a versenysport-orientált intézményeknek van, mivel olyan kialakult folyamatrendszerük van a sportélet harmonikus fenntartására, hogy ebbe nagyon könnyen beilleszthetők azok a hallgatók is, akik nem versenyszerűen, hanem csak a mozgás élvezetéért szeretnének sportolni. Az egyik ilyen egyetemen a sportiroda vizsgálja folyamatosan a hallgatói igényeket, hasonlóan egy kárpátaljai egyetemhez, ahol évente kb. 60 sportesemény kerül megszervezésre a hallgatók számára. A hallgatók igényeit az előbbi intézmény egy kialakult kérdőíves rendszerrel monitorozza, amiből olyan információk derülnek ki a vezetők számára, amikkel követhetik a hallgatók igényeit: „Azt gondolom, hogy nem szeretnék tényleg semmit kiemelni, de ami hirtelen eszembe jut, a kocsmasportok. És itt a darts, csocsó, billiárd, póker, nagyon komoly népszerüségnek örvendenek, tehát a pókerbajnokságon, még nem volt olyan, hogy ne lett volna teltház, ami, azt gondolom, hogy elég komoly rendezvény" (Versenysport-orientált intézmény2). A kikérdezés nélkül talán eszünkbe sem jutna, hogy a hallgatók körében éppen az egyik legkedveltebb sportág mondjuk a darts.

Ezen intézmény tehát több fronton is biztosít sportolási lehetőséget a hallgatói számára. A sportirodájuk és a sportintézet párhuzamosan és egymással összedolgozva szervezi a sporteseményeket: aerobic nap, fittnes órák, spinning, jóga, pilates, alakformálás és mivel 
olyan hallgatói létszámmal rendelkeznek, amit nagyon nehéz kezelni, a kialakult kérdőíves felmérések kitűnő megoldások a hatékony sportélet fenntartására.

A sport révén közösségteremtő intézményekbe tartozó egyik egyetemen az oktatók sokszor szakdolgozók segítségével vizsgálják a hallgatók sportolási szokásait és igényeit. Egyben a testnevelés tanszék kooperációban van a hallgatói önkormányzattal és közös sportrendezvényeket szerveznek. Az ebbe az intézménytípusba tartozó egyetemeknél érdemes megjegyezni, hogy kiemelt szerepkörnek tartják a sportot az egyetemi társadalmi élet alakításában és az interjúalanyok szavaiból is látható, hogy mindent megtesznek a hallgatók kényelméért, illetve egészséges életmódra nevelésükért. Egy erdélyi és az egyik kárpátaljai intézményben is heti egy órában mindenkinek kötelezően részt kell vennie a testnevelés órákon, amit a diákok nagy százalékban teljesítenek is. Az intézmények oktatói és hallgatói között olyan kapcsolat alakult ki az évek során, hogy nincs szükség igényfelmérésre, mivel a folyamatos kommunikáció miatt az oktatók naprakészek a hallgatók igényeit illetően.

A testnevelés fókuszú intézményeknek figyelembe kell venniük a hallgatók további egyetemi elfoglaltságait és igényeit is a sportórák kialakításánál, mivel a sport kevésbé határozza meg az egyetemi hallgatólétet, mint az előbbiekben vizsgált felsőoktatási intézményekben. Viszont újra megjelenik az oktatók szerepe, akik az elmondottak alapján rendkívül pozitívan és lelkiismeretesen állnak a feladatukhoz. Az egyik határon túli intézmény magyar kara kiemelt figyelmet fordít a sportos szabadidő-szervezésre a tanítószakos hallgatóinál, gondolva arra, ha kikerülnek iskolákba, önállóan tudjanak megszervezni egy ilyen eseményt. A hallgatói igényekről folyamatosan tájékozódnak az oktatók. Más intézményekben is a hallgatók igényeihez, illetve órarendjéhez próbálják igazítani a sportfoglalkozásokat, így ezeken az órákon több hallgató tud részt venni és a diákok is úgy érzik, hogy fontos a véleményük, ezért szívesebben is vesznek részt olyan órákon, amik az ő igényeikhez lettek igazítva.

„Például az aerobiknál úgy van, hogy a csoportot megkérdezi a kolléga és ahhoz viszonyítva állítja össze az órarendet. Tehát mi az első két hétben a hallgatókhoz igazítjuk a lehetöségeket. Ha például amit mi beteszünk az órarendbe, az nem felel meg a többségnek, akkor áttesszük olyan időpontba, ami neki megfelelö és akkor sokkal többen el tudnak jönni, tehát eléggé alkalmazkodunk a hallgatókhoz" (Testnevelés-fókuszú intézmény3).

A testkultúra-minimalizáló intézményekben az a tendencia figyelhető meg, hogy a tanárok önállóan szervezik a testnevelés órákat, alakítják annak tartalmát specifikusan a 
hallgatók igényeire és korábbi iskolai tapasztalataira építve. Mivel ezek az intézmények nem rendelkeznek olyan nagy hallgatói tömeggel, mint egy-egy versenysport-orientált intézmény, így az oktatók szóbeli visszajelzések alapján nyernek információt a hallgatók igényeiről és ehhez alakítják az órák tartalmát: „Úgy igyekszünk megszervezni, hogy ideérjenek, figyelembe vesszük az órarendet” (Testkultúra-minimalizáló intézmény2).

\section{Az intézményi hatás modelljeinek együttes és kölcsönhatása}

Atlas.ti program segítségével vizsgáltuk meg, hogy az általunk létrehozott kódok által az intézményi hatás egyes modelljei, dimenziói hogyan jelennek meg együtt az intézménytípusok sportéletében, tehát mely intézményi tényezőknek van tényleges hatása, milyen különbségek vannak ebben intézménytípusonként, illetve a legérdekesebb kérdés az, hogy az egyes dimenziók milyen kölcsönhatásban vannak egymással. Az 1. ábrából jól kirajzolódik, hogy a korábbi eredményeinkkel összhangban a versenysport-orientált intézményeknél láthatjuk a legtöbb tényező kölcsönhatását. Az infrastrukturális háttér lehetővé teszi a versenysport legfőbb támogatását, erre építve a kampuszmiliő kialakítását. A versenysport maga kontrasztot mutat a testnevelés szervezésével, ennek hátterében az állhat, hogy ezeknél az intézményeknél a szabadidősportot valamivel jobban előtérbe helyezik a testnevelés szervezésével szemben, mintegy kiegészítőként a versenysport mellé, ezzel is megteremtve a konstruált környezetet, hiszen ezeken a programokon mérik fel a korábbi sportmúltat a versenyzők kiválasztása érdekében, és a sportolási, esetlegesen versenyzési igényeket. $A$ személyi tényezők meglétével még nagyobb lehetőség nyílik a versenysport támogatására, valamint a sportszervezeti tényezők erősítésére, mivel a testnevelésben oktatók, illetve az intézményvezetők is elkötelezettek a versenysport iránt, olykor személyesen vesznek részt a versenysportban edzőként, illetve sportesemények szervezőiként. A testnevelés mint kötelező 
tevékenység túnik fel, amely infrastrukturálisan és szakmailag is kiemelkedő színvonalat képvisel. A két legerősebb változó: versenysport és a szabadidős sportrendezvények.

Ezzel szemben a testnevelés fókuszú intézményekben a versenysport mint a konstruált környezetet alakító tényező jelenik meg. A testnevelés szervezése az elnevezésből is adódóan ezekben az intézményekben kap a legnagyobb hangsúlyt, ehhez megteremtve az infrastrukturális és a humán erőforrást. A különböző szabadidős programok megléte azonban nem az eredményekről, hanem a jelenlétről szólnak, segítve a kampuszmiliő kialakítását. A szabadidős programok erősen kötődnek a testnevelés órákhoz, egyrészt a személyi feltételeket tekintve (nagyrészt a testnevelők a fő szervezők), másrészt a testnevelés órákon

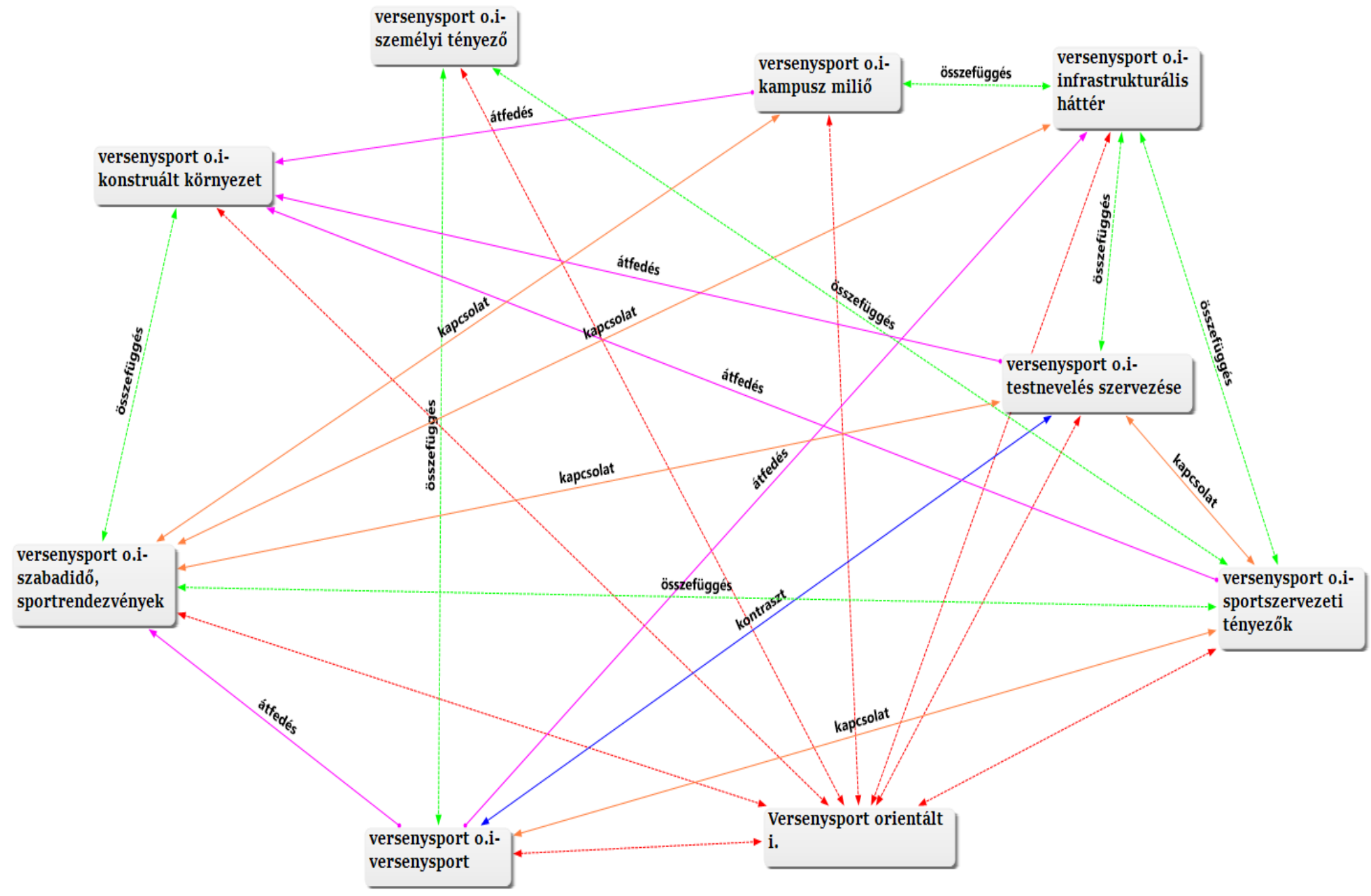

1. ábra. Az intézményi hatás modelljeinek összefüggései a versenysport-orientált intézményekben. Forrás: saját szerkesztés

megfogalmazódó hallgatói igényekhez igazodnak. Itt a konstruált környezet, valamint a kampusz miliő nem a szurkolással, hanem a közösségi élményként megélt együttmozgással alakul. A két legerősebb változó: a testnevelés szervezése és a szabadidős sportrendezvények, 
ami nem véletlen, hiszen az utóbbiak a testnevelés órákon megfogalmazódó igények és tapasztalatok alapján szerveződnek (2. ábra).

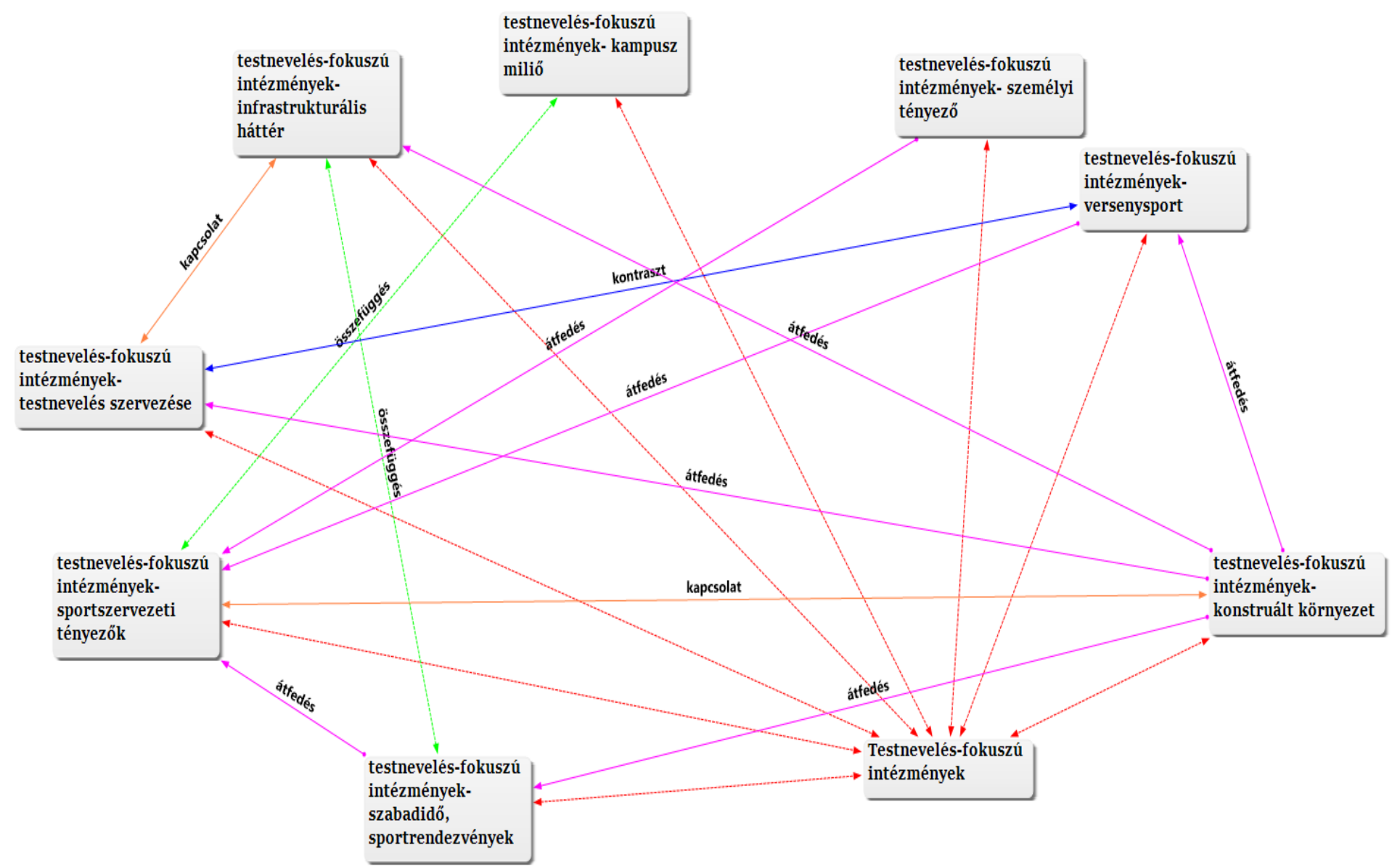

2. ábra. Az intézményi hatás modelljeinek összefüggései a testnevelés-fókuszú intézményekben. Forrás: saját szerkesztés

A sport révén közösségteremtő intézményekben az infrastrukturális háttér szoros összefüggést mutat a versenysporttal azon intézmények esetében, amelyek kedvező adottságokkal (pályákkal, termekkel...) rendelkeznek, illetve rendelkezésre állnak olyan szakemberek a szabadidős és sportrendezvények megszervezéséhez, akik ezek lebonyolításáért, valamint megszervezéséért felelnek. Itt jobban mozgósítható a hallgatóság a sportprogramokon való részvételre, a sportesemények látogatására. Ezek az intézmények kihasználják az infrastrukturális hátterüket a hallgatóság igényeinek kielégítésére és a kampuszmiliő erősítésére. A kampuszmiliőt ez esetben a közös mozgás nyújtotta élmény alkotja, aminek közösség-összekovácsoló ereje van, hozzájárul ahhoz, hogy az intézmény hallgatói és oktatói a sport révén találkozzanak, közösséget érezzenek az intézményükkel, helyenként pedig erősíti a kisebbségi magyar identitást. Az egyetem mint egy „sportcsalád” 
támogatja a versenyző hallgatóit. A három legerősebb változó, ami a többi változóval szemben megjelennek: szabadidő- és sportprogramok, kampusz miliő, konstruált környezet (3. ábra).

A testkultúra-minimalizáló intézmények tekintetében a kötelező testnevelésen kívüli sportesemények száma nem jelentős, azonban átfedés mutatkozik a konstruált környezet kialakításában és a szabadidős tevékenységek között, s ez betudható a sport (még ha nem számottevő) közösségteremtő hatásának. De ezek az intézmények a többi intézménytípustól eltérően a sportot nem használják eszköznek az „egységes erő” egyetemi identitás létrehozásához. Sem a szakmai, sem pedig az infrastrukturális háttér nem mutat szoros

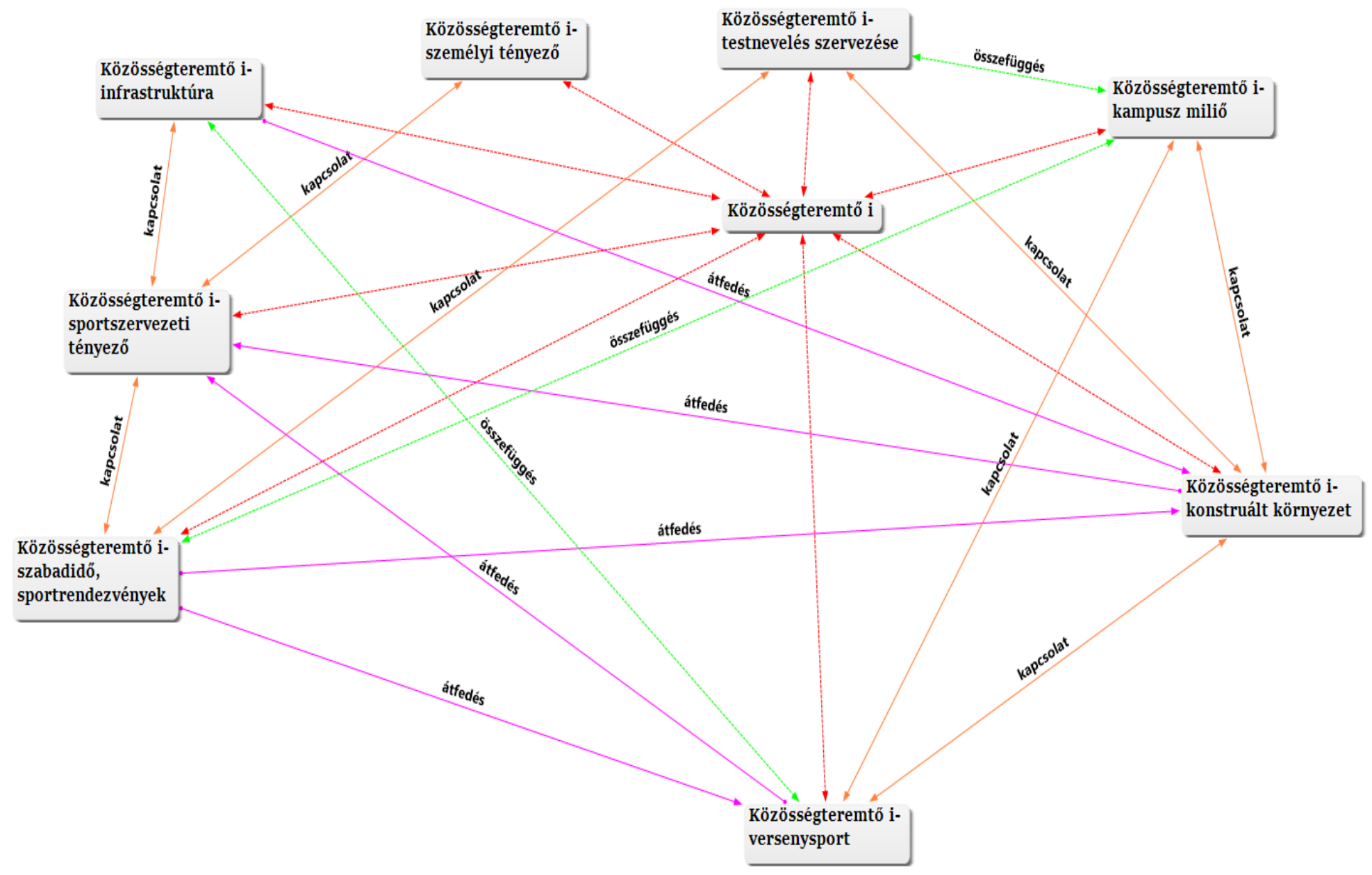

3. ábra. Az intézményi hatás modelljeinek összefüggései a sport révén közösségteremtő intézményekben. Forrás: saját szerkesztés

összefüggést egyik változóval sem, ami az interjúk alapján arra enged következtetni, hogy ezek az intézmények a testnevelésre, mint „kötelező nehézségre” tekintenek. A legerősebb vizsgált változó a testnevelés szervezése, hiszen a sportéletet gyakorlatilag csak ez jelenti (4. ábra). 


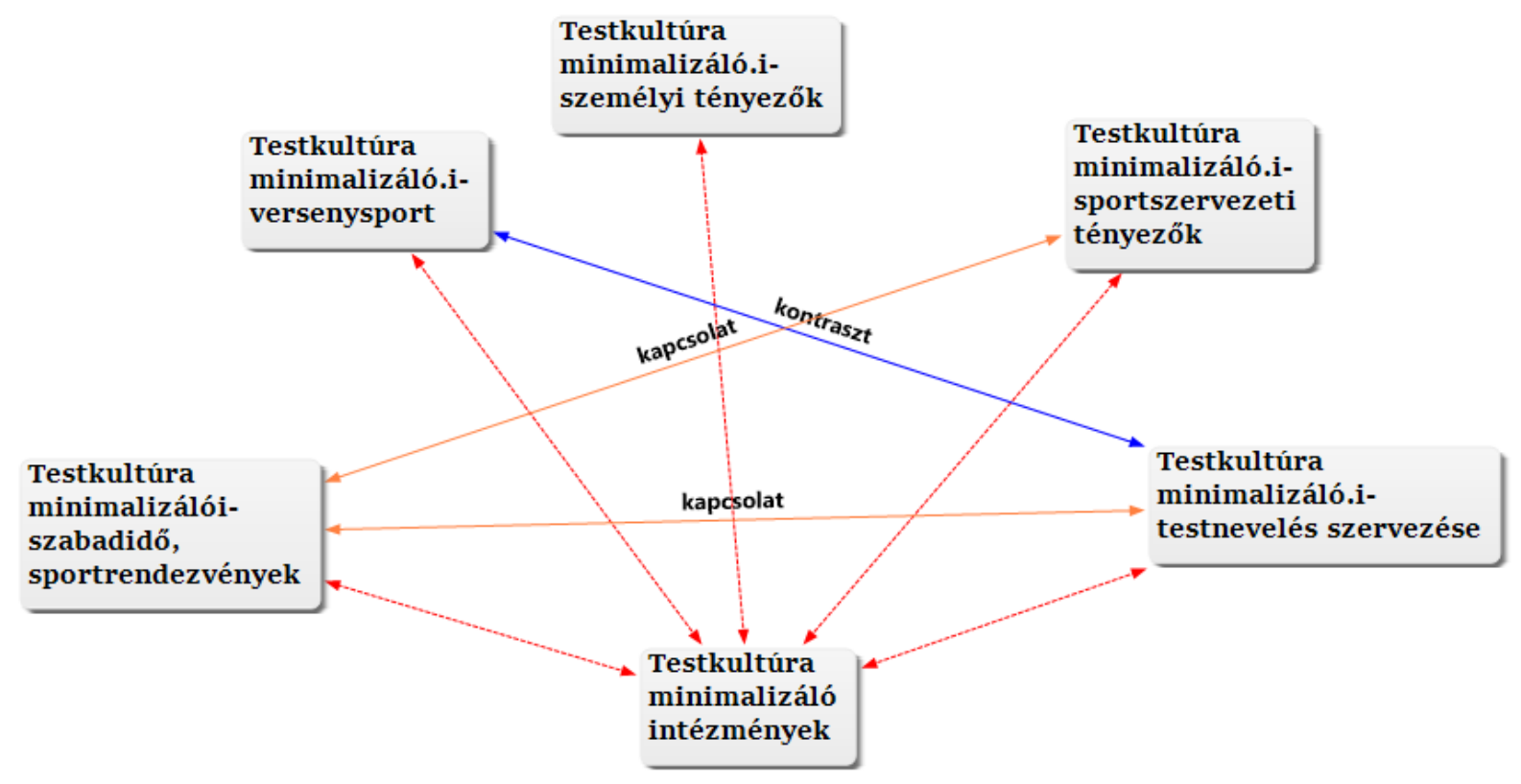

4. ábra. Az intézményi hatás modelljeinek összefüggései a testkultúra-minimalizáló intézményekben. Forrás: saját szerkesztés 


\section{Összegzés és következtetések}

Tanulmányunkban az intézményi hatás koncepcióját pedig sokdimenziós modellek segítségével vizsgáltuk meg arra keresve a választ, hogy milyen fizikai, szervezeti, emberierőforrásra koncentráló és konstruált környezeti tényezők határozzák meg a felsőoktatási intézmények sportéletét (beleértve a testnevelésórákat is) néhány Kárpát-medencei egyetemen és főiskolán. Elemzéseinkhez kvalitatív feltáró és összehasonlító vizsgálatot végeztünk: 15 interjút készítettünk 14 hazai és határon túli térség, elsősorban kisebbségi magyarokat tömörítő felsőoktatási intézményében. Kutatásunk újszerűsége, hogy a vizsgált modelleket elsősorban a hallgatói eredményesség vonatkozásában alkalmazták, tudomásunk szerint nem tesztelték még a felsőoktatási sportra és testnevelésre vonatkozóan.

Az intézményeket négy típusba soroltuk a sport szerepét és jelentőségét figyelembe véve az adott egyetemen/főiskolán. A versenysport-orientált intézményekben a sportélet meghatározó tényezője a versenysportolók támogatása, a sportsikerek népszerűsítése, s a tehetséges hallgatók versenyeken való megmérettetése. Emellett azonban fontos szerepet játszik a minél változatosabb testnevelés órák és sportprogramok szervezése, amelyek esetenként a tehetségkiválasztást és a toborzást szolgálják. A testnevelés-fókuszú intézményekben a sportéletet leginkább a mozgásos tevékenységet tartalmazó képzések és a kötelező testnevelés szervezése jellemzi. Az órákon sok esetben a középiskolai testnevelés órák hiányosságainak pótlása és atittűdformálás zajlik. A sport révén közösségteremtő intézményekben rendszerint a kötelező testnevelés órán vagy ahhoz szorosan kapcsolódó programokon a fő cél, hogy a közös mozgás, játék, sportolás során szerzett élmények közelebb hozzák egymáshoz a különböző szakokon, karokon tanuló hallgatókat, esetlegesen oktatókat. A határon túli intézményekben a közösségteremtés szorosan együtt jár a magyar identitás és kultúra megőrzésével. A testkultúra-minimalizáló intézményekben a sportéletet szinte kizárólag a kötelező testnevelés biztosítása jelenti, általában minimális infrastrukturális háttér és csak egy oktató lelkiismeretes munkája mellett.

Az interjúk elemzését követően összességében elmondható, hogy markáns különbségek fedezhetők fel az egyes intézménytípusokban a sportolás fizikai, infrastrukturális környezetét vizsgálva. Azon intézmények esetében beszélhetünk erősebb infrastrukturális háttérről, amelyekben a sportolás is kiemelkedő szereppel bír az adott egyetem életében (versenysport-orientált intézmények), így folyamatosak az ilyen célú és irányú infrastrukturális 
fejlesztések, ezeket több esetben hallgatói igényfelmérések előzik meg. Ezekben az intézményekben a sporttudományi képzésre is nagy hangsúlyt fektetnek, illetve a sporthagyományok ápolása is jelentős szereppel bír, gyakran az egyetem városának sportkoncepciójához kapcsolódnak. Mindennek az a legfőbb célja, hogy a hallgatók az egyetem kötelékébe tartozó sportegyesületek egyikébe helyezkedjenek el. A másik három kategória esetében zömmel már sokkal szegényesebb infrastrukturális háttérről beszélhetünk, ugyanakkor ezen típusú intézmények kapcsán az egyetemek küldetéstudatában sem találkozhatunk elsődleges célként a sportolás fejlesztésére, javítására irányuló törekvésekkel. Gyakran szükség lenne felújításra, az eszköztár korszerűsítésére, de ezek az igények nem mindig találkoznak a vezetőség elképzeléseivel. Hiábavalóak tehát több esetben is a sportban kompetens személyek meglátásai és a leendő fejlesztésekre irányuló törekvései, ha az adott intézmény életében nem jelennek meg prioritásként az ilyen jellegű fejlesztések. Ezen intézmények zöme nem rendelkezik sporttudományi képzéssel, azonban a sporthagyományok fenntartására és őrzésére majdnem minden intézmény hangsúlyt fektet.

A magas szintű infrastrukturális háttér potenciálisan segíti a szabadidős programok megszervezését is, valamint a konstruált környezet kialakításában is kulcsfontosságú helyet tölt be ezen rendezvények jelenléte. A testnevelés-fókuszú intézmények esetében megkönnyíti a sportrendezvények szervezését és lebonyolítását a megfelelő szintű infrastrukturális háttér, erősíti a konstruált környezetet, ami nem más, mint a hallgatók értékítélete, véleménye az intézmény sportéletéről. Ebben az esetben ez az eredmény arra utal, hogy a sport szervezésében fontos szerepe van a hallgatói véleményeknek ezekben az intézményekben, ezekre alapozva igyekeznek megszervezni a sportéletet, amely szoros összefüggésben áll a testnevelés megszervezésével. A sport révén közösségteremtő intézmények hasonlóságot mutatnak a versenyorientált intézményekkel, azonban míg az előző intézmények esetében a versenysportra fektetnek nagyobb hangsúlyt, itt a szabadidősport által építik fel a kampusz miliőt, s ez a konstruált környezet kialakításában is fontos szerepet játszik. Az egyetemi hallgatóságot egységként kezelik, ahol mindenkit megillet a sportprogramon való részvétel lehetősége. A versenysport-eseményeket sportrendezvényekként szervezik, ahol nem mint résztvevők, hanem mint látogatók biztosítják a hallgatók jelenlétét. Az egyetemeken versenysportoló hallgatókat sportösztöndíjjal támogatják. De fontosabb célok az egyetem hírnevének erősítése és a szabadidő aktív eltöltésének támogatása. 
A szervezeti környezeti tényezók közül fontos szerepe van a komplex sportstratégiának az intézmények részéről, mely jól tükrözi az intézményvezetők elköteleződését a sport iránt és beépül az egyetem imázsába. Ez egyaránt tartalmazza a fő célokat, irányelveket és elvárásokat a testnevelés-oktatásra, sportprogramokra és versenysport szervezésére vonatkozóan. Megvalósítása különösen hatékony azokon az egyetemeken, ahol többnyire a HÖK-kel együttmúködve Sportiroda, vagy kiemelten erre létrejövő intézmény múködik. Ahol nincs lehetőség ilyen szervezeti keretek között szervezni a sportéletet és a kötelező testnevelést, ott kiemelkedő szerepe van egy-egy személynek, leginkább testnevelőnek, aki hivatásként tekint munkájára, s életcéljának tekinti a mozgás megszerettetését. A szervezés során szintén meghatározó a hallgatók motiválásában a hallgatóbarát órák és programok szervezése, amely keretében figyelembe veszik a diákok időbeosztását, igényeit és korábbi tapasztalatait. A személyi tényező, az oktató egyéni példamutatása is szükséges a hallgatók sportszocializációjának formálásában. Ez akár ellensúlyozhatja az infrastruktúra, a koncepció hiányát is.

Összességében megállapítható, hogy a saját lehetőségeihez mérten mindegyik egyetem igyekszik olyan körülményeket biztosítani a hallgatói számára, hogy a sportot minél közelebb hozzák hozzájuk. Nyilván egyik felsőoktatási intézmény sem tud versenyezni egy versenysportot kiemelkedően támogató intézménytípusba tartozó egyetem infrastrukturális és logisztikai adottságával, de az kijelenthető, hogy mindegyik a lehető legtöbb lehetőséget próbálja megadni a hallgatói számára amennyiben az intézményvezetés és a HÖK kellő figyelmet és támogatást szentel az intézményi sportra. Külön kiemelendők a kisebb intézmények speciális kommunikációs csatornái a sportról, melyeket közösen alakítottak ki a hallgatóikkal, s így első kézből értesülnek a hallgatók igényeiről és a programjaikat is ezekhez igyekeznek igazítani.

\section{Abstract}

The aim of our study is to explore the institutional environmental factors of sporting life of some higher education institutions in the Carpathian Basin. Our main question is that how the models of institutional effect appear on the field of sports in the examined higher education institutions, What factors can influence the sports habits of students? 
International models was used to understand the factors of institutional effect in higher education sports. We intend to reveal and identify these indicators of the institutional effects and see how they work in the leisure-time and competitive sport of some institutions of higher education in the Carpathian Basin. relevance of examining students sporting habits and their determinants is supported by the fact that since the time spent in higher education is the last chance for students for practicing any sport activity in an organized manner (Pfau, 2014). In the framework of the study, we conducted structured interviews with physical education teachers and sport leaders in Eastern Hungary (5 interviews), as well as in Upper Hungary (1), Transcarpathia (3), Vojvodina (1), Transylvania (3) and Partium (2 interviews), particularly in higher education institutions comprising minority Hungarians or in those where a large number of Hungarian students study abroad. The investigated institutions were classified into four types based on their relationship to sport and the role of sport and physical education in the life of the university/college: (1) competition-oriented, (2) community-building through sport, (3) physical education-focused, and (4) physical education-minimizing institutions. In our study, we present the sports and constructed environment of the institutions, their organizational and infrastructural background, and the role of teachers.

Keywords: sports habits, higher education, institutional backgrounds 
Irodalom

1. Bácsné Bába, É., Fenyves, V., Szabados, G., Pető, K., Bács, Z., \& Dajnoki, K. (2018). Sport Involvement Analysis in Hungary, in the North Great Plain Region. Sustainability, 10(5), 1629.

2. Bárdos, Gy. \& Kraiciné, Sz. M. (2018). Egészség, életmód, egészségfejlesztés a felsőoktatás szemszögéből. Neveléstudomány, 6 (5), 5-21.

3. Berg, G. (2007). From structural dilemmas to institutional imperatives: a descriptive theory of the school as an institution and of school organizations. Journal of Curriculum Studies, 39, 577-596.

4. Casper, J. M., Pfahl, M. E., \& McCullough, B. (2014). Intercollegiate sport and the environment: Examining fan engagement based on athletics department sustainability efforts. Journal of Issues in Intercollegiate Athletics, 7, 65-91.

5. Chatman, J. A. \& O'Reilly, C. A. (2016). Paradigm lost: Reinvigorating the study of organizational. Research in Organizational Behavior, 36, 199-244.

6. Euler, D. (2018). Hochschulen als Orte organisationspädagogischer Forschung und Praxis. In Göhlich, M., Schröer, A. \& Weber, S. M. (Ed.), Handbuch Organisationspädagogik (pp. 767-777). Wiesbaden: Springer VS.

7. Galan, Y., Iryna, S., Zoriy, Y., Briskin, Y., \& Pityn, M. (2017). Designing an effective approach to sport for the integration in higher education institutions (the effects of yoga practice). Journal of Physical Education and Sport, 17(2), 509-518.

8. Göhlich, M., Weber, S. M., \& Schröer, A. (2016). Forschungsmemorandum Organisationspädagogik. In Schröer, A., Göhlich, M., Weber, S. M. \& Pätzold, H. (Ed.), Organisation und Theorie. Beiträge der Kommission Organisationspädagogik (pp. 307320). Wiesbaden: Springer VS.

9. Gősi, Zs. (2018). Magyarországi iskolarendszer alapú sporttámogatások. Sport, tanulás, karrier. Neveléstudomány, 6(2), 44-60.

10. Kezar, A. (2017). Organization theory and change. In Schuh, J. H., Jones, S. R. \& Torres, V. (Ed.), Student Services: A Handbook for the Profession, 6th Edition (pp. 220-235). San Francisco: Jossey-Bass.

11. Kovács, K. (2015). Magyarországi és romániai hallgatók sportolási szokásait meghatározó szocio-kulturális tényezők. In Kozma, T., Kiss V. Á., Jancsák, Cs. \& Kéri, K. 
(Ed.), Tanárképzés és oktatáskutatás (pp. 673-685). Debrecen: Magyar Nevelés- és Oktatáskutatók Egyesülete.

12. Kovacs, K. (2019). Socio-Cultural Characteristics of Sport Activity among Students in Central and Eastern Europe: Comparative empirical analysis. Journal of Physical Education and Sport, 19(1), 669-676.

13. Kovacs, K., Lentene Puskas, A., Moravecz, M., Rabai, D. \& Bacsne Baba, Eva (2018). Institutional Environment of Students' Sports Activities in Central Europe. Hungarian Educational Research Journal, 8(2), 50-68.

14. Kozma, M., Szabó, Á. \& Huncsik, P. (2016). A budapesti egyetemisták sportolási szokásai - 2004-2014. In Kovács, K. (Ed.), Értékteremtő testnevelés. Tanulmányok a testnevelés és a sportolás szerepéröl a Kárpát-medencei fiatalok életében (pp. 187198). Debrecen: Debreceni Egyetemi Kiadó, CHERD-H.

15. Kraiciné, Szokoly M. (2016). Egészségfejlesztés a felsőoktatásban - Gondolatok egy felsőoktatást érintő projekt zárása kapcsán. Opus et Educatio, 3(5), 511-528.

16. Macphail, A., Gorely, T., \& Kirk, D. (2003). Young people's socialisation into sport: A case study of an athletics club. Sport, Education and Society, 8(2), 251-267.

17. Museus, S. D. (2017). Environmental theories. In Schuh, J. H., Jones, S. R. \& Torres, V. (Ed.), Student Services: A Handbook for the Profession, 6th Edition (pp. 236-251). San Francisco: Jossey-Bass.

18. Pan, S. Y., Cameron, C., DesMeules, M., Morrison, H., Craig, C. L. \& Jiang, X. (2009). Individual, social, environmental, and physical environmental correlates with physical activity among Canadians: a cross-sectional study. BMC public health, 9(1), 21.

19. Pascarella, E. T. \& Terenzini, P. T. (2005). How college affects students. San Francisco: Jossey-Bass.

20. Pfau, C. (2014). Szabadidősport és a sportinfrastruktúra összehasonlító elemzése a kutató egyetemeken. TAYLOR, 6(1-2), 413-422.

21. Pfau, C. (2016). Hallgatói szabadidősport szervezése és jellemzői a felsőoktatásban. TAYLOR, 8(4), 5-15.

22. Pfau, C. \& Domonkos, Sz. (2016). Szabadidősport a felsőoktatásban. TAYLOR, 8(2), 111117. 
23. Prins, R. G., van Empelen, P., te Velde, S. J., Timperio, A., van Lenthe, F. J., Tak, N. I. \& Oenema, A. (2010). Availability of sports facilities as moderator of the intention-sports participation relationship among adolescents. Health Education Research, 25(3), 489497.

24. Pusztai, G., Kovács, K. E., Kovács, K. \& Nagy, E. B. (2017). The effect of campus environment on students' health behaviour in four Central European countries. Journal of Social Research \& Policy, 8(1), 125-138.

25. Renn, K. A. \& Patton, L. D. (2017). Institutional identity and campus culture. In Schuh, J. H., Jones, S. R. \& Torres, V. (Ed.), Student Services: A Handbook for the Profession, 6th Edition (pp. 58-72). San Francisco: Jossey-Bass.

26. Sallis, J. F., Bowles, H. R., Bauman, A., Ainsworth, B. E., Bull, F. C., Craig, C. L. \& Matsudo, S. (2009). Neighborhood environments and physical activity among adults in 11 countries. American Journal of Preventive Medicine, 36(6), 484-490.

27. Schein, E. H. (2010). Organizational Culture and Leadership. San Francisco: Jossey-Bass. 28. Schemmann, M. (2018). Institutionentheoretische Grundlagen der Organisationspädagogik. In Göhlich, M., Schröer, A. \& Weber, S. M. (Ed.), Handbuch Organisationspädagogik (pp. 187-197). Wiesbaden: Springer VS.

29. Silver, H. (2003). Does a University Have a Culture? Studies in Higher Education, 28, 157-169.

30. Smart, J. C., \& John, E. P. S. (1996). Organizational Culture and Effectiveness in Higher Education: A Test of the "Culture Type" and "Strong Culture" Hypotheses. Educational Evaluation and Policy Analysis, 18, 219-241.

31. Smerek, R. E. (2010). Cultural Perspectives of Academia: Toward a Model of Cultural Complexity. In Smart, J. C. (Ed.), Higher Education: Handbook of Theory and Research (pp. 381-423). New York: Springer.

32. Sporn, B. (1996). Managing university culture: an analysis of the relationship between institutional culture and management approaches. Higher Education, 32, 41-61.

33. Strange, C. C. (2003): Dynamics of campus environments. In Komives, S. R. \& Woodard, D. B. Jr. (Ed.), Student Services: A Handbook for the Profession (pp. 297-316). San Francisco: Jossey-Bass.

34. Soos, I., Dizmatsek, I., Ling, J., Ojelabi, A., Simonek, J., Boros-Balint, J., Szabo, P., Szabo, A., \& Hamar, P. (2019). Perceived Autonomy Support and Motivation in Young People: 
A Comparative Investigation of Physical Education and Leisure-Time in Four Countries. Europe's Journal of Psychology, 15(3), 509-530.

35. Szolár, É. (2009). Szervezetelméletek a felsőoktatás-kutatásban. Új Pedagógiai Szemle, 27-46.

36. UNESCO (2015). Fenntartható Fejlődési Célok. Retrieved from: http://www.unis.unvienna.org/unis/hu/topics/sustainable_development_goals.html 2020. 06. 30.)

37. Wiltshire, G., Lee, J., \& Williams, O. (2019). Understanding the reproduction of health inequalities: Physical activity, social class and Bourdieu's habitus. Sport, Education and Society, 24(3), 226-240. 


\section{Melléklet}

\section{Interjúvázlat}

Kérem, mutatkozzon be! Mi a beosztása az intézményben, milyen szerepet tölt be a sportéletében? Mióta dolgozik itt stb.?

\section{Társadalmi, intézményi tényezők}

\section{Intézményi háttér}

Milyen intézményi háttere van a sportnak az egyetemen (intézet, központ)? Mi a feladata, küldetése?

Van-e sporttudományi képzés? Milyen? Van-e tervben akkreditálás?

Hogyan értékeli a sport szerepét az egyetem küldetéstudatában? Megjelenik-e valamilyen dokumentumában? Milyen formában és szinten?

Milyen sporthagyományai vannak az intézménynek? És városnak? Ehhez kapcsolódik esetleg az intézmény?

Mely sportágakat emelné ki? Miért ezeket? Mi határozza meg, hogy pont ezeket (tanárok, infrastruktúra, diákok érdeklődése stb.)?

Meséljen az intézmény versenysport múltjáról! Milyen szervezeti keretei, eredményei vannak? Hogyan változott az egyetemen versenysportja az elmúlt évtizedekben (a rendszerváltás óta főként)? Van-e egységes logója, öltözéke? Mit szimbolizál ez?

\section{Szabályzat tesivel kapcsolatban}

Milyen testnevelési kötelezettségeik vannak a hallgatónak? (kötelező?, kredit, vagy órarend alapú, heti hány óra)

Mutassa be, kérem, hogyan biztosítja az intézmény a tesi órák teljesítését hallgatóik számára!

Ez kb. hány hallgatót érint félévente?

Mennyire jelent gondot ennek biztosítása?

Milyen formában és módon teljesíthetik az intézményen kívül?

van-e minőségellenőrzés a tesiórákról?

vannak-e oktatói, hallgatói visszajelzések?

Ha igen, hogyan jelezhetnek vissza?

Milyenek a visszajelzések?

Mire törekednek a tesiórákkal, mi a fő cél és érték a tesiórákon?

van-e sportszakmai program: mit tartalmazzanak a tesiórák? Mire kell odafigyelni? Milyen pedagógiai elemeket tartalmaz? Hogyan jelenik meg az egészségre való és élethosszigtartó sportra nevelés (ha megjelenik)? 
mennyire szigorú a követelményrendszer? Milyen mozgástere van ebben és az órák tartalmában az oktatónak?

Mennyire élményközpontúak ezek?

\section{Hallgatói sport}

Vannak információik a hallgatók sportolási szokásairól? Honnan? Mik ezek, mit emelne ki ezek közül? Mennyire kísérik figyelemmel? Ezen belül is, mire teszik a hangsúlyt (gyakoriság, elvárások, sportágak, divat stb.?)

Mi játszik szerepet a sportolásukban Ön szerint? (az intézmény és más intézményen kívüli lévő lehetőségek, illetve az egyéni felelősség)

Milyen sporteredményekkel érkeznek a hallgatók? Egy egyetem/főiskola honnan értesülhet ezekről? Önöknél mi a jellemző (milyen szintű eredmények, a hallgatók mekkora hányadát érinti stb.)?

Milyen arányban vannak versenysportolók az egyetemen?

Hogyan egyeztetik össze a hallgatók a sportot és a tanulást? Az intézménynek milyen szerepe van ebben? Tud mondani konkrét esetet, gyakorlatot?

Hogyan motiválják a hallgatókat a versenysport folytatására, abban való részvételre?

Van-e információjuk arról, hogy egyes hallgatók abbahagyták a sportolást? Mi lehet ennek az oka? Van-e tudomásuk olyan sportol(k)ról, aki(k) az egyetemre kerülve kezdtek el sportolni, versenyezni?

Felhasználják-e őket az egyetem népszerűsítésében? Hogyan?

Kitüntetések, díjak, elismerések? Mik ezek? Miért fontosak?

Van-e tehetség-kiválasztás és -gondozási rendszer, Mutassa be!

\section{Rendezvények, programok}

Milyen tömeg sportrendezvényei vannak az egyetemnek? Mik ezek célja?

Hogyan szerveződik ez? (HÖK, speciális intézmény, hallgatóknak van szerepe?

Milyen arányban vesznek részt a hallgatók, oktatók ezeken? vannak-e kedvezmények a számukra? Mik a legnépszerúbbek a körükben?

Vannak-e visszajelzések ezekről?

Milyen igények fogalmazódnak meg a hallgatók, oktatók részéről? Honnan informálódnak ezzel kapcsolatban?

Milyen egészségfejlesztő programokat tudna mondani, aminek a rendszeres sportolásra való nevelés is része? Mi a célja ezeknek?

Hogy érzi, milyen hatékonysággal múködnék ezek (elérik a célt, egészségtudatosabbak lesznek a hallgatók ettől?)

\section{A hallgatók egészségi és edzettségi állapota}

Vannak-e információik, esetleg az Ön intézménye méri-e a hallgatók egészségi és edzettségi állapotát? Van-e országos program erre? Ehhez képest a valóságban hogy zajlik? 
Ha igen, milyen gyakran, milyen formában? Miért? Mit? Mire fektetik a hangsúlyt?

Mit kezdenek az adatokkal?

Ha nem, miért nem?

Érezhető-e a mindennapos testnevelés hatása a belépő I. évfolyamnál, akiknek már van tapasztalatuk ezzel kapcsolatban?

\section{Kötelező tesi szigorítása}

Mit gondol növelni kellene-e/vagy bevezetni a kötelező testnevelést? Miért? Milyen formában?

Milyen előnye és hátránya lenne?

Milyen fogadtatása lenne a hallgatók, oktatók körében?

Ön szerint hogyan lehetne a mindennapos testnevelést felhasználni a hallgatók motiválására a rendszeres sportolásra?

\section{Ökológiai tényezök}

Mutassa be, milyen infrastruktúrával rendelkezik az intézmény/város, amit használnak? (csarnokok, tornatermek, pályák, kondiparkok, uszoda stb.) (hány db, mi van, milyen felszereltségű stb.)

Szükség van-e külső infrastruktúra használatára? Mire? Miért?

Milyen kihasználtságúak ez az infrastruktúra?

Milyen időrendben működnek?

Kik használhatják, mikor, milyen feltételekkel? (hallgatók, dolgozók, a nap melyik szakjában, hétvégén? Ingyen?)

Mikor voltak felújítva? Újak építve?

Vannak-e hallgatói, oktatói visszajelzések?

Mi hiányzik esetlegesen?

Terveznek-e létesítményfejlesztéseket, beruházásokat, felújításokat?

Van-e rá forrás? Miből (normatíva, állami, pályázat)? Mire számíthatnak?

megfelelő-e az eszközpark az egyes sportágak tesióráihoz? Milyen minőségúek? Milyenek a visszajelzések, ha vannak?

Megjelenik-e a környezettudatosság az infrastruktúrákban? Milyen formában?

\section{Gazdasági tényezök}

Szerepel-e külön a sport az egyetemi költségvetésben? Milyen arányban lehet rá költeni, ha igen? milyen (egyéb) forrásokból finanszírozzák az infrastruktúra fenntartását? Pályázatok, együttmúködések más szervezetekkel?

Sportrendezvényeket és programokat?

Jelent-e anyagi problémát az infrastruktúra fenntartása, rendezvények, programok szervezése? 
Mire lehet fordítani? van-e szabályozás?

van-e sportösztöndíj? Milyen részei vannak? milyen kritériumai vannak az elnyerésének?

Milyen forrásokból bonyolítják a versenyeztetést? elegendő-e, szükség van-e más forrásokra? Milyen típusú versenyekre a MEFOB-on túl?

A sportrendezvények, programok milyen arányban fizetősek, ingyenesek? Amik fizetősek, a bevételt mire fordítják?

Az infrastruktúrákból és sportszolgáltatásokból vannak-e bevételek? Mire fordítják?

Milyen egyéb sportszolgáltatások vannak?

\section{Személyi tényezők}

Hány főállású oktató, testitanár van? Hány óraadó? Hány minősített oktató? Hány szakedző? (nagy intézmény esetében elég a kb. százalékos megoszlás ezekre a kérdésekre)

Milyen képzettségúek? Milyen sportágakban?

Edzőként dolgoznak-e? Részt vesznek-e versenysportokban? Mikben? Milyen arányban? Egyetemen belül vagy utánpótlásban?

Milyen szakmai és pedagógiai kritériumokat várnak el az oktatóktól?

Hogyan jelenik meg ebben az egészségnevelés?

Mi az oktatók hozzáállása a sporthoz (vannak-e, akik jelenleg is sportolnak, versenyeznek, esetlegesen a diákokkal együtt sportolnak/versenyeznek? lehetnek-e példaképek? Mondjon példákat (nem neveket)!)

Bekapcsolódnak-e sportrendezvények, programok szervezésébe? Milyen formában?

A jövőben terveznek-e bővítést? Milyen területen? Milyen sportágakat illetően?

előfordulhat-e létszámleépítés?

Hogyan biztosítják, illetve ellenőrzik a tanárok folyamatos szakmai fejlődését?

\section{Lezárás}

Összességében mit gondol, hogyan járul hozzá az intézmény a hallgatók rendszeres sportolás és az egészségtudatosság igényének kialakulásához, fenntartásához?

Milyen hosszú és rövidtávú tervei vannak az intézmény sportéletének fenntartásához és fejlesztéséhez kapcsolódóan? 